Giuseppe Stabile (Napoli)

iD https://orcid.org/0000-0002-1427-9466

\title{
Rumanian Slavia as the Frontier of Orthodoxy The Case of the Slavo-Rumanian Tetraevangelion of Sibiu
}

In the Tetraevangelion also known as the Slavo-Rumanian Evangeliarion of Sibiu ${ }^{1}$, the slow sunset of the Slavonism seems to face the dawn of the Rumanian literary tradition. Not only is it the earliest extant text in Slavonic and Rumanian languages, but it is also the earliest provided with parallel bilingual transcription, and the only version of the Gospels printed in such a form, at least in the $16^{\text {th }}$ century ${ }^{2}$.

Regardless whether it originally contained all four - or just three - Synoptic Gospels, only two fragments of the SRT are preserved today, both from the Gospel of Matthew:

1. the more extensive one (ff. $\left.1^{\mathrm{R}}-117^{\mathrm{v}}, \mathrm{Mt} 3,17-27,55\right)$, in the Saltykov-Ščedrin Library in Saint Petersburg;

2. the shorter one (ff. $36^{\mathrm{V}}-37^{\mathrm{R}}$, Mt $12,12-28$ ), in the Orthodox Church of Oiejdea (Alba Iulia), where it was discovered in the 1970s ${ }^{4}$.

\footnotetext{
${ }^{1}$ Evangheliarul slavo-român de la Sibiu (1551-1553), ed. E. Petrovici, L. Demény, Bucureşti 1971 (cetera: SRT).

${ }^{2}$ Cf. G. MiнĂILĂ, Textele bilingve slavo-române și unele aspecte ale studiului calcului lingvistic, [in:] Contribuţii la istoria culturii și literaturii române vechi, București 1972, p. 236-244, esp. 241. For a critical up-to-date overview on the SRT, cf. I. GHeţie, A. MAReș, Originile scrisului In limba română, București 1985, p. 337-342; E. PAVEL, Textul evanghelic în cultura românească, LR 66, 1, 2012, p. 30-31.

${ }^{3}$ Cf. L. Demény, Evangheliarul slavo-român de la Sibiu - Prima tipăritură în limba română cunoscută pînă azi, [in:] SRT, p. 22-98.

${ }^{4}$ Cf. E. MÂrzA, Un fragment din Evangheliarul slavo-român de la Sibiu (1551-1553), LR 27, 2, 1978, p. 173-175 (= Explorări bibliografice, Sibiu 2008, p. 14-16).
} 
Only a handful of fragments of the indirect tradition of the SRT were identified in Codicele Bratul ${ }^{5}$, a Slavo-Rumanian intercalated miscellaneous text, which contains - among other texts - parts of the Acts of the Apostles and the Gospels, copied perhaps in Southern Transylvania and dated 1559-1560 by Pop Bratul, the copyist himself ${ }^{6}$.

While the Slavonic text - late and "peripheral" - has been almost entirely overlooked by Slavists, the parallel Rumanian one used to arouse a certain interest among Rumanists, especially after it was discovered, about half a century ago, that it was the earliest preserved printed text (the Catehism luteran de la Sibiu, printed in 1544 and considered to be the earliest, has not survived) ${ }^{7}$.

Actually, the SRT has to be considered as a bilingual text, an icastic metaphor for a multiple frontier - linguistic, but also chronological, geographic and cultural - by which our text is crossed and obviously defined.

Since it came out of the printing press in Sibiu between 1551 and 1552-1553, the SRT contains the earliest preserved Rumanian translation of the Gospels, made probably after 1526 (assuming the translation, as well as the printing of the SRT, was of Lutheran origin indeed). The SRT print followed shortly the appearance of the first writings in Rumanian vernacular and signed the beginning of the slow decline of Slavonism, a process which had to span more than one century. In fact, it was not before the $18^{\text {th }}$ century that Rumanian became the official language of the Church, State, and written culture, replacing Church and chancery Slavonic.

The translation and the final edition of the Rumanian text took place, respectively, in Banat or Moldavia and Transylvania, that is on the frontier between the Orthodox East with its Byzantine-Slavic tradition, and the Catholic or Reformed Latin West.

In the mid- $16^{\text {th }}$ century, the majority of Rumanians formed still part of the so called Slavia Orthodoxa: Rumanian Orthodoxy was firmly based on the primacy of the Church Slavonic, which, while not implying any official ban on using vernacular as the language of worship or in the Scripture, did not encourage it

\footnotetext{
${ }^{5}$ Cf. Codicele Bratul, ed. A. Gafton, Iaşi 2003 (cetera: CB) (= http://media.lit.uaic.ro/gafton/txt/text [26 IX 2016]).

${ }^{6}$ Gheţie and Mareş observed the following correspondences in the fragments of Mt 26, between CB and SRT: vv. 7, 14-8, 20 and 24 - SRT ff. $105^{\mathrm{R}}{ }_{11-13}, 105^{\mathrm{v}}{ }_{16^{-}}-106^{\mathrm{R}}{ }_{5,10-14}, 106^{\mathrm{v}}{ }_{1-2}$; CB ff. $440_{16-19}, 441_{1-20}$. Cf. I. Gheţie, Al. Mareș, Originile scrisului..., p. 336-357 and G. Mihăılă, Primul manuscris românesc pre-coresian datat: Codicele Popii Bratul din Brașov (1559-1560) și sursele sale, [in:] Studii de lingvistică și filologie, Timișoara 1981, p. 64-71.

${ }^{7}$ In 1965, access to the microfilm with the entire text and unprecedented flowering of paleographic and philological studies revolutionized the knowledge of the SRT, that had achieved little progress since 1891 (the printing had been dated back to 1580, assuming the 1579 Slavonic Tetraevangelion of Coresi as a terminus a quo). About the progress occurred in dating the SRT since the middle of the 1960s, cf. I. GHEŢıE, [rec.:] Evangheliarul slavo-român de la Sibiu 1551-1553... - SCL 23, 6, 1972, p. 664-670 (esp. p. 666-667).
} 
either, rightly claiming that it contributed to the spread of heresies ${ }^{8}$. In this regard, the printing of the Slavo-Rumanian Tetraevangelion represented a formal compromise between the Lutheran proselytism, which almost certainly inspired the Rumanian translation, and the Slavonic tradition.

However, the same necessity for such a compromise indicates that a cultural boundary continued to exist between the two parallel texts of the SRT, and that the Rumanian text (or rather the biblical use of Rumanian vernacular) was still beyond it.

Bearing in mind that the contrast between the Latinity of language and the Slavicity of rite was just starting to emerge, the fact that, in the $16^{\text {th }}$ century, a number of texts appeared featuring parallel or alternated Rumanian and Slavonic, may be explained in two ways:

1. Slavonic was less and less known and had to be translated not so much for the faithful, as for the uneducated Orthodox clergy (especially in Transylvania, where Orthodoxy was discriminated and consequently no stable Orthodox hierarchy existed at that time $)^{9}$;

2. at most, the Rumanian text could integrate the canonical one in Slavonic, although its use was not allowed in the liturgy ${ }^{10}$.

As a consequence, the Church Slavonic was itself beyond a linguistic boundary, though it had, apart from its liturgical, sacral value, a kind of identitarian value: throughout the Middle Ages and later, the spiritual and linguistic communion (Slavonism) with the Orthodox Slavs were the principal, if not the unique mainstay of the Rumanian identity, especially in those frontier areas where Rumanian Orthodoxy was exposed to Catholic or Protestant proselytism ${ }^{11}$. Only thanks to the Union with Rome accepted by the majority of the Orthodox Church of Transylvania (1698-1700) and the consequent emergence of the "Latinist School", the Romanity by descent and the Latinity by language would play such a role ${ }^{12}$.

\footnotetext{
${ }^{8}$ Significantly, still in 1698 , the instructions of Dositheos, Patriarch of Jerusalem, to the Neo-Metropolitan of Transylvania, Athanasiu, indicated church Slavonic and Greek as the sacred languages to be used in the Orhtodox liturgy and in the comments on the Scripture, restricting the use of Rumanian to sermons - if addressed to Rumanians, and reading of the Gospels, but the latter only in the first 1688 official translation (the so called Bible of Bucharest). Cf. Acte si fragmente latine romanesci pentru istori' a Beserecei romane mai alesu unite, edite si adnotate, ed. T. CIPARIU, Blasiu 1855 , p. 243-244.

${ }^{9}$ Cf. C. Alzati, Terra romena tra Oriente e Occidente. Chiese ed etnie nel tardo '500, Milano 1981, p. 89-98, 99-105.

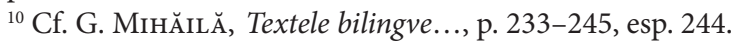

${ }^{11}$ Cf. C. Alzati, Terra romena..., p. 89-90.

${ }^{12}$ Cf. L. VAlmarin, La latinità dei rumeni come arma politica dalla Scuola transilvana a oggi, [in:] La latinité hier, aujourd'hui, demain, Actes du Congrčs international procurés par Georges et Ilinca
} 
The printing of the Tetraevangelion in Rumanian a few years after the Catechism, was an unprecedented event, and yet the appearance of these two Church books in vernacular was quite typical for the Lutheran proselytism.

There are no more than two translations inspired by Protestantism in the Rumanian text of the SRT, concealing a radical condemnation of the Orthodox ecclesiastical hierarchies, one of "Pharisee" with duhovnic 'confessor, spiritual (priest)', the other of "high priest" with mitropolit 'metropolitan', vlădică and piscup 'bishop'13.

Needless to say, the SRT, already as a product of the Lutheran proselytism for Rumanian of Orthodox faith, would cross a linguistical and cultural frontier with the West of the Reformation and its local representatives, the Saxons, Hungarians, but also reformed Slavs, of both Latin and Orthodox origins ${ }^{14}$. The latter, like the Rumanians, are better known for their loyalty to Orthodoxy, loyalty which has not prevented them from contributing to the activity of the Transylvanian Cyrillic presses established by "Latins" (reformed Saxons or Hungarians) ${ }^{15}$.

Filip Maler "the Moldavian", the printer and probably the editor of the SRT, can also be seen as a "frontier-figure". A native of Moldavia or Banat, Filip was almost certainly a Saxon, and as such he belonged to a community that shared strong Latin traditions, in recent times converted to Hussitism and later to Lutheranism $^{16}$.

Between 1521 and 1554, a Magister Philippus is mentioned in the Konsularrechnungen of Sibiu in the service of the city government as a typographer, engraver/

Barthouil-Ionesco, Avignon - 10-13 mai 1978, ed. G. BARThouil, I. BARTHouIL-Ionesco, Bucarest 1981, p. 403.

${ }^{13}$ Cf. I. Gheţı, A. Mareş, Originile scrisului..., p. 342.

${ }^{14}$ They were a part of what I would call the little Slavia transylvanica mixta, community of Czechs and Slovakians, but also Bulgarians, Serbians and Ruthenians, not to mention the Şchei. Between the $15^{\text {th }}$ and the $16^{\text {th }}$ century, Rum. Şcheau designated Bulgarians from Transylvania (and perhaps Rumanians coming from Bulgaria), mainly Orthodox, but among which the Lutheran and Catholic propaganda seem to have found proselytes in a significant number, cf. F. MıкLośich, Die Sprache der Bulgaren in Siebenbürgen, Wien 1856, р. 2; Л. Милетич, Дако-ромбнитп и тпхната славянска писменость, II, Нови влахо-български грамоти оть Брамовъ, СНУНК 9, 1896, р. 9-17, 29. About etymology and meaning of Rum. Şcheau, cf. also I. Hurdubeţıu, Originea Scheilor și răspîndirea lor pe teritoriul carpato-dunărean, SAIst 14, 1969, p. 196-199, 202-204; about Şcheau/Bulgar alternation in Transylvanian documents, A.M. GHeRman, Lexic românesc în documente transilvănene. Socotelile orașelor Brașov și Sibiu, D [s.n.] 13, 1, 2008, p. 57.

${ }^{15}$ Hard to say, realistically, whether their contribution was motivated by a missionary spirit or by profit. Cf. P. Atanasov, L'imprimerie en Roumanie et les bulgares de Braşov au XVI ${ }^{e}$ s. (La collaboration culturelle bulgaro-roumaine au XVI ${ }^{e}$ s.), EB 6, 1967, p. 123-139.

${ }^{16}$ Cf. I. GHeţıE, Consideraţii filologice asupra Evangheliarului din Petersburg, SCL 17, 1, 1966, p. 54, 61, 77; IDEM, Evangheliarul slavo-român de la Sibiu și textele românești cu litere latine și ortografie maghiară, LR 28, 2, 1979, p. 84; A. MAREș, Observații cu privire la Evangheliarul din Petersburg, LR 16, 1, 1967, p. 72 and IDEM, Evangheliarul din Petersburg, tipărirea unei mai vechi traduceri moldovenești, LR 17, 1, 1968, p. 86. 
illustrator (Moler/pictor), scribe and translator of "Wallachian" (scriba/interpres), and a liaison and envoy to the Rumanian countries ${ }^{17}$. In 1544, the versatile typographer was commissioned by the Saxon authorities of Sibiu - recently converted to the Lutheran Reformation - to print the (now lost) Rumanian Catechism and in 1546 the Slavonic Tetraevangelion ${ }^{18}$, whose colophon bears the signature Филипь Мо(А) Аов'Енинь ${ }^{19}$.

Considering his functions, it is highly probable that apart from German and possibly Latin, Filip knew Slavonic and Rumanian. He presumably knew the kind of Slavonic used in tribunals, legislation and chancery rather than the ecclesiastical one, while he had a practical knowledge of Rumanian, as a non-native speaker but grown up in constant relation with the Rumanophone communities.

Since as a non-Orthodox layman he did not have access to higher education in Slavonic, it was impossible for him to receive it in Rumanian: at the time, no literary tradition existed, much less biblical, in the vernacular, only recently and sporadically used in its written form (a handful of proto-translations of the Gospels we know would be seen as pioneering and isolated attempts).

Even if the title of Magister/Meister implied not the craft but higher education - as Hervay assumed ${ }^{20}$ - it did not include litterce slavonica or rutenicales: sons of Saxon nobility received Western Catholic or Protestant education, preferably in Cracow, Prague, Vienna or some German city ${ }^{21}$.

The fact that Filip and his "bottega" (assistants) printed alongside the Tetraevangelion in Church Slavonic does not tell us which knowledge they had of this language: the Slavonic text of the SRT is a faithful reprint of the SST, which, in turn, was a faithful reprint of the Slavonic Tetraevangelion printed in Târgovişte by the Hieromonk Makarije of Montenegro in $1512(\operatorname{Trg})^{22}$. Reprinting the SST had

${ }^{17}$ Cf. P. Binder, A. Huttmann, Contribuţii la biografie lui Filip Moldoveanul, primul tipograf român. Evoluţia vieţii culturale românești la Sibiu în epoca umanistă, LL 16, 1968, p. 150-156, 165, 170-174. ${ }^{18}$ Tetraevanghel slavonesc, Sibiu 1546, BAR II 630838 (cetera: SST).

${ }^{19}$ Cf. N. IoRga, Cinci comunicări la Academia Română, III, Tipărituri româneşti necunoscute, RI 17, 1-3, 1931, p. 9-10; L. Demény, Evangheliarul slavo-român..., p. 81-88; contra P.P. PANAitescu, Les origines de l'imprimerie en langue roumaine, RESEE 6, 1, 1968, p. 26.

${ }^{20}$ Cf. F. Hervay, L'imprimerie du maître Philippe de Nagyszeben et les premiers livres en langue roumaine, MK 81, 2, 1965, p. 124-125.

${ }^{21}$ Cf. Ș. Papacostea, Moldova în epoca Reformei. Contribuţie la istoria societăţii moldovenești in veacul al XVI-lea, SRI 11, 4, 1958, p. 61 and R. MANOLESCU, Cultura orășenească în Moldova în a doua jumătate a secolului al XV-lea, [in:] Cultura moldovenească în timpul lui Ștefan cel Mare, ed. M. BERZA, București 1964, p. 79-81.

${ }^{22}$ Cf. Das Tetraevangelium des Makarije aus dem Jahre 1512. Der 1te kirchenslavische Evangeliendruck. Faksimile-Ausgabe, ed. H. Miklas et al., Padeborn-München-Wien-Zürich 1999 (cetera: Trg). The first allusion to typographical analogies between the SRT and the Trg can be found in P. SîRKu (cf. [rec.] Psaltirea publicată la 1577 de Diaconul Coresi, Reprodusă cu un studiu şi glosar comparativ la B. Petriceicu-Haşdeu - ЖМНП 228, 1883, p. 393). The discovery that, except for sporadic omissions and spelling differences, the Trg, the SST and the SRT contain the same text can be attributed to Emil Petrovici apud L. Demény, O tipăritură slavo-română precoresiană, SRI 18, 5, 1965, p. 1031. 
the obvious advantage of reduced time and costs, not to mention that no particular knowledge of Slavonic was required. Moreover, the text was the first printed Slavonic Tetraevangelion and, if that was not enough to make it more authoritative, it contained a poslédoslovie by Voivode Neagoe Basarab who made it de facto an "official" edition ${ }^{23}$.

Crossing the Carpathians, however, the Trg seems to have undergone some significant adjustments to the Lutheran milieu in the paratext.

In the prédislovie to the Gospel of John, written by Theophylact of Ohrid, two sentences were omitted that the Sibian editor apparently considered to be too openly at odds with Luther's Reformation:

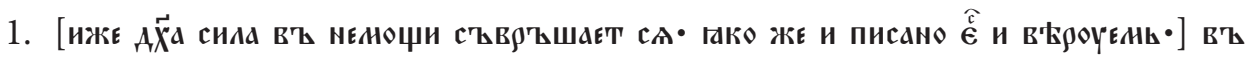

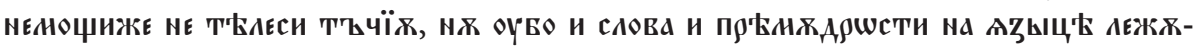

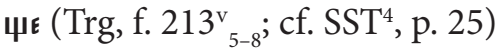

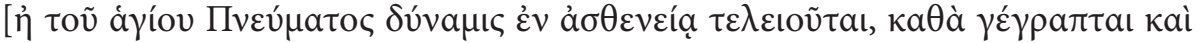

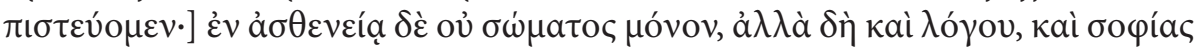

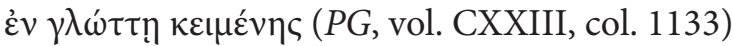

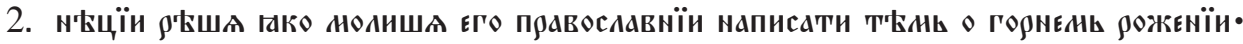

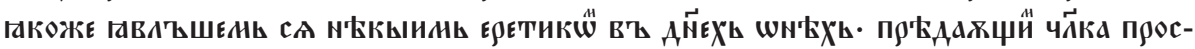
тавыти I’ca (Trg, ff. $214^{\mathrm{R}}{ }_{19}-214^{\mathrm{v}}$; cf. SST ${ }^{4}$, p. 26)

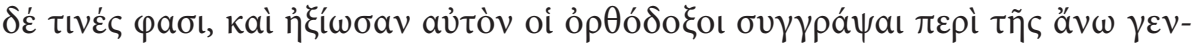

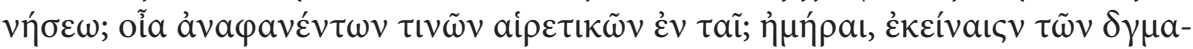

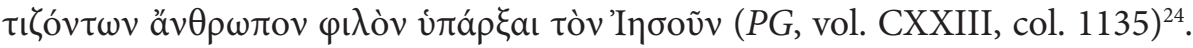

In the first one - as far as we know, this omission has never been noticed so far - Theophylact commented on 2 Cor 12, 9 explaining that, as Paul points out, if the power of the Holy Spirit is fully manifested in its "weakness», this should be referred not to the flesh but to the word and the knowledge, which John, a man

Cf. L. Demény, D. Simonescu, Un capitol important din vechea cultură românească (Tetraevanghelul, Sibiu 1546), SCDB 1, Supl., 1965, p. 11 and A. MAREș, Precizări cu privire la traducerea Tetraevanghelului lui Coresi, SCL 18, 6, 1967, p. 664-665.

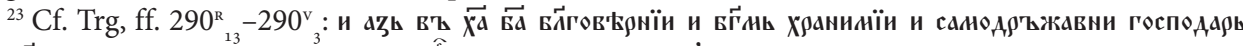

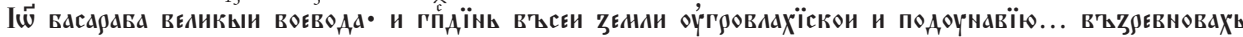

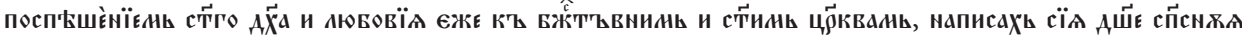
Книгж четво९овйГОвТсттїє...

${ }^{24}$ The preface of Theopylact was reproduced, without any omission, not only by Makarije, but also by Coresi and Tudor in Braşov, in 1562, and by Lavrentie in Plumbuita, in $1575 \mathrm{ca}$. Cf. Tetraevanghel slavonesc lui Coresi (Braşov 1562), BAR III 234272 (cetera: CST), ff. $159^{\mathrm{R}}{ }_{14-19}, 159^{\mathrm{v}}{ }_{1-6}$ and Tetraevanghel slavonesc lui Lavrentie or de la Plumbuita (1575 ca.), BCU-Cluj BRV 34 (cetera: PST), ff. $149^{\mathrm{v}}{ }_{12-14}, 150^{\mathrm{R}}{ }_{20-25}$. 
of humble origins, was lacking. The overzealous Sibian editor may have thought that Theophylact's comment clashed with Luther's doctrine, according to which God's Word (the Gospel) is the supreme symbol and testimony of the Revelation, the only nurturing of the faith (and in the faith, der Glaube aber ist es, wenn er gleich klein und schwach ist, God reveals Himself in all His power and greatness) ${ }^{25}$.

In the second sentence - pointed out by Demény in $1965^{26}$ - the Evangelist was described as a defender of Orthodoxy against heresy (according to Theophylact, at the request of some Orthodox Christians, John meant to confute an heresy that denied the eternal conception of the Christ by attributing Him a solely human nature). In fact, the sentence was omitted together with an entire fragment of the text in which Theophylact referred to the same heresy (Trg, ff. $214^{\mathrm{R}}-214^{\mathrm{v}}{ }_{11}$ ), then replaced by a part of prédislovie to the Gospel of Mark, where, in the form of a prophetic vision (cf. Apoc 4, 7 and Ezk 10, 14), Theophylact symbolically described the Four Evangelists ( $\operatorname{Trg}$, ff. $83^{\mathrm{v}}{ }_{11}-84^{\mathrm{R}}{ }_{6}$ ).

As for the possible Lutheran origin of such omissions, it should be also noticed that they all concern the Gospel of John and the Epistles of Paul, that Luther famously put first in the context of the New Testament ${ }^{27}$.

In summary, it can be said with reasonable certainty that the Trg, an editio princeps of the Slavonic Tetraevangelion reprinted in the left-hand column of the SRT:

1. is different from the text printed in the CST and the PST ${ }^{28}$, but on par with all other sacred texts printed by Makarije in Wallachia,

2. is a clear example of the Middle Bulgarian redaction and Euthymian orthography, with occasional Serbian redactional features ${ }^{29}$, and

\footnotetext{
${ }^{25}$ Cf. M. Luther, Predigt am vierten Sonntage nach Epiphanias, [in:] Hauspostille, vol. II, ed. J.G. PlochMANn, Erlangen 1826, p. 47. Cf. also R.H. BAInTON, The Reformation of the $16^{\text {th }}$ Century, Boston 1952, p. 44-45 (esp. 45: For him [Luther] the ultimate authority was the word of God, by which he meant the self-disclosure of God through the incarnation, the crucifixion, and the resurrection of Christ. This revelation was not restricted in time to the historical life of Jesus, because Christ is eternal and ever at work in the hearts of men, but the supreme manifestation was in flesh. The Bible is the record of this stupendous event).

${ }^{26}$ Cf. L. Demény, D. Simonescu, Un capitol important..., p. 11 and L. Demény, Evangheliarul slavoromân..., p. 90.

${ }^{27}$ Cf. R.H. Bainton, The Reformation..., p. 45.

${ }^{28}$ Cf. A. Mareş, Originalele primelor traduceri româneşti ale Tetraevanghelului și Psaltirii, [in:] Scriere și Cultură Românească Veche, București 2005, p. 261-263 (= Cele mai vechi texte românești. Contribuţii filologice și lingvistice, ed. I. GHeţıE, București 1982, p. 185-187).

${ }^{29}$ P.P. Panaitescu talks about a text "cu foarte rare sîrbisme" [with extremely rare Serbianisms]. Cf. Liturghierul lui Macarie (1508) și începuturile tipografiei în ţările române, [in:] Contribuţii la istoria culturii românești, București 1971, p. 304 (the most recent contributions to the topic are substantially concordant: F. Miklas, Das Tetraevangelium des Makarije aus dem Jahre 1512
} 
3. documents a rather established version of the Athonite Slavonic text, dated between the end of the $15^{\text {th }}$ and the beginning of the $16^{\text {th }}$ century (Voskresensky's "fourth redaction" of the Slavonic Tetraevangelion), the most faithful to the textual Byzantine tradition, although Nemirovsky discovered in it some original "Wallachian" variants and, for the first time, some Eastern-Slavonic ones, claiming that Makarije should have been familiar with the Eastern-Slavonic manuscript tradition (especially the liturgical rubrics of the manuscript source would have been edited, according to Miklas, von einem nicht-Bulgaren $)^{30}$.

The SST and the SRT also inherited from the Trg the typographic dress, which, in the form of the semi-uncial type and ornamentation, cannot be seen in the Serbian editions of Venetian school but in the Moldavian manuscripts of Bulgarian school. Therefore the two Transylvanian Tetraevangelia attest the beginning of an original and partially "native" typographic tradition (note that the Wallachian manuscripts had been influenced by the Moldo-Bulgarian tradition before the printed books) ${ }^{31}$. It should be reminded, in this regard, that the style of the Moldavian scriptoria also influenced the production of Schweipolt Fiol's ephemeral typography - the first Cyrillic - who was active in Cracow between 1481 and 1492-1493, and which must have come into contact with Moldavia and Transylvania $^{32}$.

As an engraver and illuminator of Moldavian descent, Filip developed the characters of the Cyrillic typography of Sibiu partially imitating the ones used by Makarije and possibly being inspired by a direct knowledge of the manuscripts copied in the Moldavian scriptoria ${ }^{33}$.

Since the paratexts remain the unique trait d'union between the Trg and the books already printed by Makarije in Cetinje - as well as the main confirmation

(Einleitung: Sprache), [in:] Trg, p. XIX; Е.Л. НЕмировский, Начало книгопечатния в Валахии, Москва 2008, p. 546-548).

${ }^{30}$ С. Д. Иванова, Търговищкото печатно Евангелие (1512 г.) и старите славянски преводи на Евангелието (с оглед на текстологичната традииия), [in:] Българистични проучвания, vol. I, Велико Търново 1996, p. 46-57; Das Tetraevangelium..., p. XIX, XXXV-XLI; Е.Л. Немировский, Начало..., p. 523-524; A. Alberti, Gli scriptoria moldavi e la tradizione medio-bulgara. Il caso del Vangelo di Elisavetgrad, [in:] Linee di confine. Separazione e processi di integrazione nello spazio culturale slavo, ed. G. Moracci, A. Alberti, Firenze 2013, p. 34, 50.

${ }^{31}$ Cf. L. Demény, Cartea şi tiparul. Promotori ai legăturilor culturale dintre ţările române în secolul al XVI-lea, SMIM 6, 1973, p. 92-94; D. Deletant, A Survey of Rumanian Presses and Printing in the $16^{\text {th }}$ Century, SEER 53, 131, 1975, p. 162-163.

${ }^{32}$ Cf. L. Demény, L'imprimerie cyrillique de Macarios de Valaquie, RRH 7, 3, 1969, p. 557.

${ }^{33}$ Cf. F. Hervay, L'imprimerie du maître Philippe..., p. 121, 125-126; L. Demény, Typographische Kennzeichen der kyrillischen Druckerpresse in Hermannstadt im 16. Jahrhundert, FVL 19, 1, 1969, p. 29-36; IDEM, Evangheliarul slavo-român..., p. 85-87; E. TuRdEAnu, L'activité littéraire en Moldavie à l'époque de Etiènne le Grand (1457-1504), [in:] Etudes de littérature roumaine et d'écrits slaves et grecs des Principautés roumaines, Leiden 1985, p. 113-161 (= RER 5/6, 1960, p. 21-66). 
that the Montenegrin and the Wallachian Makarije are the same person ${ }^{34}$ - the SST colophon itself introduces a new and probably relevant element: Filip dated this printing both in the Latin way, from the Incarnation $(\mathbf{A} \Phi$ sis. $=1546)$, and in the Byzantine way, from the Creation (зін $\mathbf{A} .=7054)$, but most of all, he added the Dominical letter $($ нєАєлноє слово $\vec{\Gamma}=3$ ), even rarer in the Rumanian editions of the $16^{\text {th }}$ century and clearly Latin too ${ }^{35}$.

The presence of two Latin chronological elements among other Byzantine ones is a reflection of the frontier milieu, a Latin-Orthodox blend, where the SST was printed and where Filip "the Moldavian" was educated and/or learned the art of printing. Assuming that Filip was a layman of Lutheran faith, his apprenticeship had to be made rather in a German typography than in an Orthodox monastery, perhaps even in Hermannstadt-Sibiu, where, between 1528 and 1530, the first typography with Latin script in Transylvania had been functioning ${ }^{36}$. From Moldavia, the children of middle-class merchants and artisans - mostly non-native (German, Hungarian, Polish or Czech) - were sent to Transylvania or to their motherland, in order to receive better education or to learn or hone their skills ${ }^{37}$.

Furthermore, between the end of the $15^{\text {th }}$ and the beginning of the $16^{\text {th }}$ there was no documented typographic activity, neither in Moldavia nor in the nearby Maramureş ${ }^{38}$, despite a manuscript production, still flourishing and evolving at the time (cf. the boierească [noble] edition of the Slavonic Tetravengelion, which appeared in Moldavia at the beginning of the $16^{\text {th }}$ century, less expensive and luxurious than the domnească [voivodal, lordly] one) ${ }^{39}$.

What remains unknown, however, is in particular the source from where Filip derived the Littera Dominicalis for the colophon of his SST, since it cannot be attributed to any of the typographical models most likely to have inspired him (including the Serbian-Venetian) ${ }^{40}$.

\footnotetext{
${ }^{34}$ Cf. P. Atanasov, L'imprimerie en Roumanie..., p. 124-125; P.P. Panaitescu, Liturghierul lui Macarie..., p. 316-319.

${ }^{35}$ Cf. D.P. Bogdan, Contribuţiuni la bibliografia românească veche. Tipărituri dintre anii 1546-1762 necunoscute la noi, București 1938, p. 6. (Already conclusive about the identification of the "two Makarijes" was DeménY in L'imprimerie cyrillique de Macarios..., p. 550-551, 560-561).

${ }^{36}$ Cf. F. HervaY, L'imprimerie du maître Philippe..., p. 122 and Z. JAkó, Szeben latin betüs könyvnyomtatása a XVI. században, [in:] Írás köniv értelmiség, Bukarest 1976, p. 180-183.

${ }^{37}$ Cf. R. Manolescu, Cultura orăşenească în Moldova..., p. 49-56.

${ }^{38}$ Cf. L. Demény, Cartea şi tiparul..., p. 104.

${ }^{39}$ Cf. M. Székely, I. Biliarsky, Tetraevanghelul Ieromonahului Macarie din Putna (1529), Apu 2, 2013, p. 60.

${ }^{40}$ There is no trace of nedelnoe slovo neither in the colophon used by Makarije in Cetinje and Tîrgoviște (1494-1495 and 1508-1512), nor in those used by Schweipolt Fiol in Cracow (1491-1493), Theodor Ljubavić in Goražde (1519-1523) and Božidar Vuković in Venice (1519-1521, 1536-1539), cf. Е.Л. Немировский, Славянские издания кирилловского (иерковнославянского) шрифта: 1491-2000. Инвеантарь сохранившихся экземпляров и указатель литературы, vol. I, (1491-1550), Москва 2009, p. 101, 115-116; Liturghier slavonesc lui Macarie (Târgovişte 1508) - BAR II 170567,
} 
As a result, at least two other hypotheses should be taken in consideration:

1. Filip could have been influenced by Latin manuscript practice, which he probably knew in a country of Latin traditions, maybe in Transylvania, Moldavia and/or Wallachia ${ }^{41}$;

2. the Trg is not the real antigraph of the SST or at least not the only one; in other words, the apograph derives from another, similar but not identical manuscript or it is the fruit of a collation with another manuscript, bearer of a Latin influence (in Transylvania and Moldavia, Catholic, Hussite and Lutheran versions of the Holy Scriptures were virtually accessible at the time $)^{42}$.

Further indications that Filip Maler's education was at least partially western can be found in his illustrations with anthropomorphic figures of the SST, rarely found in the Rumanian and Slavic codicological panorama still after the $16^{\text {th }}$ century ${ }^{43}$. The style of Filip's engravings - so different from the Byzantine colourful miniatures in the Tetraevangelion of Elisavetgrad and Ivan Alexander - seems to betray the eclecticism of a Latin illustrator, as a Saxon could be ${ }^{44}$. An analogous style can be found, in fact, in the woodcuts of the Octoechos printed in Cracow (1491) by the German-born Schweipolt Fiol and in the Pentecostal Triduum printed by the Deacon Coresi in Târgovişte (1558), believed to have been illustrated by a Saxon and/or inspired by Fiol's work ${ }^{45}$. According to Mareş, Filip could have reproduced his engravings from a printed text of western origin, namely Serbian-Venetian ${ }^{46}$.

p. 258; Octoih slavonesc lui Macarie (Târgovişte 1510) - BAR II 630846, p. 63; И.П. КAРATAeB, Onuсание славяно-русских книг, напечатанных кирилловскими буквами, СОРЯС 34, 2, 1883, р. 5 , 7, 17-18, 20, 79-80, 87, 94).

${ }^{41}$ Cf. R. MAnolescu, L'écriture latine en Valachie et en Moldavie au Moyen Âge, RRH 25, 1-2, 1986, p. 59-68.

${ }^{42}$ Cf. I.-F. Florescu, Le Tetraévangile de Sibiu (1551-1553). Nouvelles informations sur les sources de la premičre traduction en roumain des Evangiles, BJas 1, 2010, p. 40-41, 43.

${ }^{43}$ Cf. L. Demény, Evangheliarul slavo-român..., p. 84-85.

${ }^{44}$ The Church Slavonic Tetraevangelion of Elizavetgrad (end of $16^{\text {th }}$ century?), Moldavian, reproduces decorative and iconographic apparatus of the Trnovian Ivan Aleksander's Tetraevangelion (1356), considered in its turn "an unicum". In Stephen the Great's Moldavia (1433-1504), however, the Byzantine-Bulgarian manner of illustrating the Gospels' episodes spread beyond the scriptoria, being itself exposed to other influences. Cf. E. Dragnev, O capodoperă a miniaturii din Moldova medievală. Tetraevanghelul de la Elizavetgrad ţi manuscrisele grupului Parisinus Groecus 74, Chişinău 2004, p. 169-180; A. Alberti, Gli scriptoria moldavi..., p. 24-25; E. Moussakova, The Illustrated Slavonic Miscellanies of Damascenes Studite's Thesauros - A New Context for Gospel Illustrations in the 17th century, [in:] Byzantine and Post-Byzantine Art: Crossing Borders, Exploring Boundaries. Art Readings. Thematic Peer-reviewed Annual in Art Studies, vol. I, Old Art, ed. E. Mutafov, I. Tотн, София 2017, p. 325-326, 339-340.

${ }^{45}$ Cf. A. Sokolyszyn, Sweipolt Fiol: The First Slavic Printer of Cyrillic Characters, ASEER 18, 1, 1959, p. 90 and V. Molin, Ilustraţia în vechea carte bisericească, BOR 78, 7-8, 1960, p. 705.

${ }^{46}$ Cf. A. Mareş, [rec.] Demény L., L.A. Demény, Carte, tipar şi societate la Români în secolul al XVI-lea..., LR 27, 5, 1988, p. 479-481 (but cf. also Д. МедАковит, Графика српских штампаних къига XV-XVII века, Београд 1958, p. 119). 
As a Saxon, Lutheran, and layman, Filip was an exception in the Rumanian typographic panorama of the $16^{\text {th }}$ century, populated mainly by Orthodox clergymen, supposedly consisting - at least in Sibiu and Braşov - of deacons and popes from Şcheii and Răşinari. In Braşov-Kronstadt, Coresi’s assistants were local members of the clergy, Şchei or "Wallachian", often employed by the Stadt-Notar as Walachischer Schreiber or Stadt-Loguffet, position rarely held by Saxons or Latins (in Sibiu, Filip and Ioachim Maler - presumably father and son - seem to have been the only Saxons holding it, Filip being perhaps the only one who combined it with that of Stadt-Typograph $)^{47}$. Another layman, albeit of Orthodox Serbian origin, was the Logofet Dimitrije Ljubavić, son of Đurađ and grandson of Božidar. Dimitrije's typography - active in Târgovişte between 1544 and 1547 - employed Jerodiakon Moysi Dečanski ${ }^{48}$ and at least two Şchei or Rumanian apprentices, Oprea and Petru, from Şchei (perhaps members of the local Orthodox clergy, instructed at the church school of Sf. Nicolae $)^{49}$.

Hieromonk Makarije was also helped by priests - Serbian in Cetinje and, more likely, Şchei in Târgovişte - in an Orthodox milieu (Makarije himself and his assistants would have been Şchei, but educated in a German milieu, perhaps in Cracow, according to Atanasov) ${ }^{50}$.

Filip Maler's assistants remain anonymous, and yet had they been Orthodox priests, their names would have been presumably mentioned in the colophon of the SST to increase the authority of the Sibian Tetreavangelion, as a guarantee of its Orthodoxy.

Neither in Moldavia, nor much less in Banat and Transylvania - where the "schismatic" Church was still discriminated - the Lutheran Reformation had reason to encourage its proper faithful to learn Slavonic, if not for practical or contingent purposes (affecting individual Lutherans and/or their communities, never the Reformed Church as a whole $)^{51}$. With this in mind, it is hard to believe that

\footnotetext{
${ }^{47}$ P. Binder, A. Huttmann, Contribuţii..., p. 146-149; IDEm, Intre istorie şi filologie, I. Mediul cultural românesc al Braşovului în epoca coresiană, LR 20, 1, 1971, p. 10-11, 14.

${ }^{48}$ Moysi was native of Budlja; as an assistant of Vuković, Karataev wrongly attributed to him Moldavian origins, the error was amended by Simonescu. С. И.П. КАРАтаев, Описание славяно-русских книг..., p. 89; J. BADALIĆ, Jugoslavica usque ad annum 1600. Bibliographie der südslavischen Frühdrucke, Aureliae Aquensis 1959, p. 47 (D. Simonescu, Un Octoih al lui Bojidar Vucovici la noi şi legăturile acestuia cu tipografia românească, RIR 3, 2/3, 1933, p. 229).

${ }^{49}$ Cf. P.P. Panaitescu, Începuturile şi biruinţa scrisului în limba română, București 1965, p. 137, 169; P. Atanasov, L'imprimerie en Roumanie..., p. 127.

${ }^{50}$ Cf. P. Atanasov, L'imprimerie en Roumanie..., p. 125.

${ }^{51}$ Not even among the Latins converted to the Bohemian Reformation the knowledge of the Slavonic language was more than exceptional: the Hussites of Transylvania, Maramureş and Moldavia always used vernacular - Czech, Saxon, Hungarian and perhaps Rumanian - for preaching and cult. Only locally they went far enough to vulgarize single parts of Holy Scriptures and Church books. Cf. J. MACŮREK, Husitství v rumunských zemích, ČMM 51, 1927, p. 3, 40, 56-58, 77; Istoria Romîniei, vol. I, ed. A. OŢETEA, M. Berza et al., Bucureşti 1962, p. 702. It does not make the contacts between single Hussites and Orthodoxy less likely, especially in Moldavia and Maramureş (Veress noticed that
} 
the printing of the sacred books in Church Slavonic could have had, for the Lutheran editors of Sibiu, other purposes beyond the commercial ones.

Our current knowledge on the SRT texts describes an environment in which the contribution of Orthodox clergymen was seemingly marginal, to say the least:

1. the Slavonic text is, until proven otherwise, a reprint of the $\operatorname{Trg}$ (the edition of the sacred texts in Slavonic at the typography of Sibiu was limited to two faithful reprints of the same text);

2. translation errors present in the Rumanian text reveal that both its translators and final redactors had a flawed understanding of the Slavonic and Rumanian language (it may be presumed that the Sibian typography remained a Latin one converted to Cyrillic to operate in a Rumanian-Orthodox context) ${ }^{52}$.

By contrast, there is little doubt that the Rumanian text of the SRT was translated and printed primarily for missionary purposes (notwithstanding the possibility of a final review that would make it better accepted by the Orthodox authorities of the Principalities). The scant circulation of the books printed in Rumanian at Sibiu - relatable to what's left of them today - shows the difference between its reception beyond the Carpathians ${ }^{53}$. Apart from the original sin of being issued by "the Heresy Press", the same flaws of the Rumanian redaction (first of all the Saxon inflection) could have had in this a significant role.

The Rumanian text of the SRT remains the principal source of information not only about Filip Maler and his assistants but also about the border environment in which it was edited and printed. From the archaic and lively Rumanian emerges a clear predominance of the Banat-Hunedorean and Moldavian features over the South-Eastern Transylvanian (i.e. Sibian) and Muntenian ones (Gheţie talked about two strata of language, the one Banatean and the other Moldavian $)^{54}$.

The unique colouring in the panorama of the first Rumanian translations of the Bible comes from alloglot inflexions - Saxon, Hungarian and Ruthenian - which

\footnotetext{
Németi György, a Hungarian of perhaps Saxon origins, copying the Huszita Biblia in Trotuş [1466], abbreviated the nomina sacra in the Slavonic-Byzantine and not in the Latin form [e.g.: Is vs. IHs], cf. E. Veress, Bibliografia Română-Ungară, vol. III, Românii în literatura ungară şi Ungurii în literatura română (1839-1878), Bucureşti 1935, p. 18).

${ }^{52}$ On both issues, cf. also I.-F. Florescu, Le Tetraévangile de Sibiu..., p. 45-47.

${ }^{53}$ It is also true that at least in one case the Rumanian Catechism - presumably the "most Lutheran text" printed in Sibiu - was even requested by a voivode of Wallachia (in 1556, the documents of Braşov register the payment of 12 aspra $1 / 2$ pro Catechismo valachico Matheo ferenti a Cibinio..., recipient Pătraşcu cel Bun [1545-1557]). Cf. P. Binder, A. Huttmann, Contribuţii..., p. 165-166.

${ }^{54}$ Cf. I. GHEŢıE, Baza dialectală a românei literare, București 1975, p. 219-221.
} 
place the Rumanian text of the SRT on the frontier between East and West (certainly Saxon are considered the confusion between articulated and unarticulated forms, the unvoicing of consonants and the epenthetic diphthongs $)^{55}$. Banatisms would apparently derive from the translation, while Moldavisms and Transylvanisms form the redaction for printing, as are the Saxonisms and other alloglotisms, which, however, might derive from both translation and redaction ${ }^{56}$. The translation made in Banat-Hunedoara, or by someone who presumably was from there, would have been collated with Luther's German text and assembled for printing by some Saxons from Moldavia, in the mixed milieu of Sibiu ${ }^{57}$.

It has been observed ${ }^{58}$ that only if the revisor and/or printer of the Rumanian text of the SRT was a Saxon or a non-native, one could explain:

1. the presence of alloglot features in the orthography, not in the syntax, of the Rumanian text and

2. the fact that the final revisor didn't amend words which he should have been presumably able to identify as atypical or wrong in case he was a mother-tongue Rumanophone.

By choice or necessity, the Lutheran authorities of Sibiu would have entrusted their official translator for the "Wallachian" language with the final revision of the text, despite his Saxon origins and probably the lack of solid priestly background.

In fact, such a peculiar presence of alloglotisms in the text printed at Sibiu suggests that the Lutheran revision was inspired by typographical and/or editorial requirements, mostly already reported by the critics, such as e.g.:

1. transliterating in the Cyrillic script and Rumanian spelling a text originally edited in the Latin script ${ }^{59}$ and Hungarian spelling ${ }^{60}$, without being - in all likelihood - neither Rumanian nor Hungarian;

\footnotetext{
${ }^{55}$ Cf. A. Mareș, Evangheliarul din Petersburg..., p. 86; E. Petrovici, Observaţii asupra grafiei și limbii textului românesc al Evangheliarului Slavo-Român de la Sibiu, [in:] SRT, p. 19 and T. BodogAE, Și totuşi prima carte romanească s-a tipărit la Sibiu. Consideraţii despre Evangheliarul slavo-român din 1551-1553, MArd 17, 1-2, 1972, p. 86. For a more extended list of the alloglotisms containted in the SRT, cf. I. GHeŢı, Considerații filologice..., p. 54, 56, 61-64.

${ }^{56}$ Cf. A. Mareş, Originalele..., p. 266.

${ }^{57}$ Cf. I. Gheție, A. Mareş, Originile scrisului..., p. 341.

${ }^{58}$ Cf. A. Mareş, Observaţii..., p. 73.

${ }^{59}$ Cf. E. Petrovici, Observaţii..., p. 18.

${ }^{60}$ Cf. I. Gheţıe, [rec.:] Evangheliarul..., p. 84.
} 
2. reorienting a text edited in the Latin milieu toward an Orthodox-Slavonic milieu, that is a Rumanian proto-translation, bearing "Latin" influences (ascribable maybe to Carpatho-Danubian outcomes of the Hussite Reform) ${ }^{61}$,

3. assembling a fragmentary and/or incomplete text, perhaps a translation made in haste by different translators, including Rumanians and Saxons (the hypothesis may be compatible with an ad hoc translation made for a bilingual edition, just before the printing $)^{62}$;

4. collating and harmonizing the original Rumanian translation with Luther's German one and to the parallel Slavonic text (respectively real and fictitious model of the Rumanian text) ${ }^{63}$.

The collation with Luther's New Testament - irregular and inaccurate ${ }^{64}$ - explains the prominent role of Saxons, at most bilingual, in the editing of the Rumanian text, printed by Filip Maler. One would expect that such a revision had the most sensitive part of the religious vocabulary as its main objective (cf. the heretic translation of "High Priest"), without requiring a perfect knowledge of Rumanian or Slavonic.

There is no doubt that the contribution of a Saxon German-Rumanophone represented the unique alternative to a complex collaboration between Saxons and Rumanians, ignorant of their respective languages (the final result suggests that the second possibility was rejected due to time constraints).

On the other hand, the unfavourable conditions in which Luther's Reformation had to take root - already around 1525-1530 - among Catholic and Orthodox "Wallachians" of the Banat-Hunedoara, suggest that the original translation could have been executed by a "Wallachian", not even a reformed one, maybe, knowing Slavonic but not German, who necessarily didn't base his work on the Septembertestament (it's slightly doubtful that his Lutheran commissioners had the integral text of Luther's New Testament) ${ }^{65}$. Under the same, unfavourable,

${ }^{61}$ Florescu talks about "un prototype roumain", translated, without doubts, from Church Slavonic [qui] présentait des concordances textuelles avec les traductions tchèques (notamment 'Bible Olomoucká') et allemandes $d u X V^{e}$ siècle. Cf. I.-F. Florescu, Le Tetraévangile de Sibiu..., p. 70-83.

${ }^{62}$ Cf. A. Mareş, Originalele..., p. 266; L. TASmowski, În ajunul unei ediţii transliterate și electronice a Evangheliarului bilingv slavo-român de la Sibiu, [in:] Per Teresa. Studi e ricerche in ricordo di Teresa Ferro, vol. II, Obiettivo Romania, ed. G. Borghello et al., Udine 2009, p. 334.

${ }^{63}$ Cf. A. Mareş, Originalele..., p. 267.

${ }^{64}$ Cf. Ibidem, p. 263-265; L. TASmowski, În ajunul unei ediţii..., p. 332-335 and I.-F. Florescu, Le Tetraévangile de Sibiu..., p. 47-50.

${ }^{65}$ Cf. P. BInder, Inceputurile Reformei din Transilvania şi Românii din Hunedoara, LR 20, 3, 1971, p. 273-275; I. GHețiE, Textele rotacizante şi originile scrisului literar românesc. Chestiuni de metodă, [in:] Începuturile scrisului în limba română, Bucureşti 1974, p. 22-24, 170-171. 
conditions the Lutheran Reformation reached Moldavia, where, at that time, «quidam doctor» is said to have translated the Gospels and Acts of the Apostles into Rumanian, bringing his translation directly to Wittenberg (he presumably wanted it to be printed and approved by the supreme Protestant authorities ${ }^{66}$.

The communis opinio is that the Rumanian SRT text was translated from Church Slavonic, precisely from the parallel Slavonic text, that is from the Trg via the $\mathrm{SST}^{67}$. It cannot be excluded, however, that the translation is not based on the Trg, but on a related text, as for instance its main antigraph, which remains unknown. In that regard, the Trg presents difficulties being not a simple copy that reproduces the antique manuscripts word by word, but a text in which a significant contribution of its editor (and also the translator) may be noticed ${ }^{68}$.

It has been observed ${ }^{69}$ that two untranslated Slavonisms contained in the Rumanian text of the SRT - although the Trg is of Middle Bulgarian redaction - display the acc. $-o y / 10$ of the m. sg. with -a-/-ja- stem, as is typical of Serbian, Russian and Lithuano-Ruthenian redactions. This redactional feature, though so sporadic, is

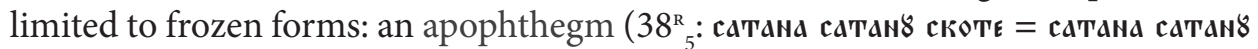
изгонить [Satan cast out Satan], cf. Mt 12, 26) and a Hebrew toponym difficult to pronounce $\left(77_{6}^{\mathrm{v}}\right.$ : Вия.дфагыю = Виюссфагї, [Bethphage], cf. Mt 21, 1). Furthermore, none of the two examples of $-\mathrm{oy} / \mathrm{to}$ for $-\boldsymbol{x} / \mathrm{w}$ can be found in Trg, only one (catan8) in SST (cf. Trg, f. $33^{\mathrm{R}}{ }_{19-20}$; SST, p. 63), which suggests a combination of another antigraph, if not a reflexion of the "workshop" of Filip Maler ${ }^{70}$. The Sla-

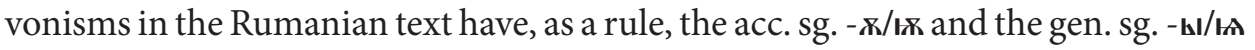
of the masculines and feminines with - $a-/-j a-s t e m$, as is typical of Middle Bulgar-

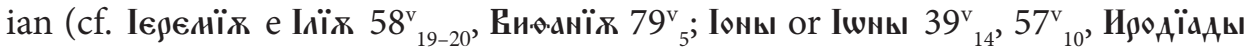

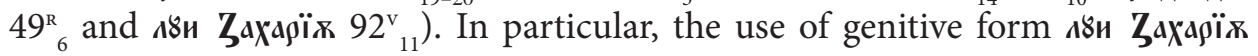

\footnotetext{
${ }^{66}$ Cf. Ş. Papacostea, Moldova în epoca Reformei..., p. 62-63; A. Rosetti, Cu privire la datarea primelor traduceri românești de cărţi religioase, LR 7, 2, 1958, p. 20-21 (= Du nouveau sur la date des premières traductions roumaines de livres religieux, Rom 80, 317, p. 80-81). Someone identified doctor ex Walachia, vir canus, qui non germanice sed latine et polonice loquitur with the same Filip Maler (cf. L. Demény, Evangheliarul slavo-român..., p. 97, contra I. GHEŢıE, [rec.:] Evangheliarul..., p. 668-669; the latest contribution on the issue and on the role of the Moldavian Saxons in the diffusion of Lutheranism, in P. PHILIPPI, Ein Moldauer 1532 als Bibelübersetzer?, [in:] Land des Segens? Fragen an die Geschichte Siebenbürgens und seiner Sachsen, Köln-Weimar-Wien 2008, p. 105-109 [= ZSL 13, 1, 1990, p. 19-22]).

${ }^{67}$ The first to propose that was Ioan Bogdan at the end of the $19^{\text {th }}$ century (originalul slav se afla in faţa traducerii românești), cf. I. BoGDAN, O Evanghelie slavonă cu traducere română din secolul al XVI-lea, ConvLit 25, 1, 1891, p. 36, 38.

${ }^{68}$ С. Д. Иванова, Търговищкото..., p. 46, note 6-7; варем, Печатните български книги от ХVI век и старата ръкописна традиция, ТКШ 6, 1999, p. 295-311.

${ }^{69}$ Cf. E. Petrovici, Observaţii..., p. 14.

${ }^{70}$ The forms in -ж/к (cf. сотона сотонж and Витфаћика) also prevail in the varice lectiones of the most ancient Church Slavonic tradition of the Gospel of Matthew. Cf. Евангелие от Матфея в славянской традиции, А.А. АлексеЕв, А.А. ПичхадзЕ et al., Санкт-Петербург 2005, p. 67, 110.
} 
lui Zaharia in the Rumanian text of SRT confirms the tendency to trace the biblical names of the parallel Slavonic text in their original form ([А० к'ьрвє] Zахарїк)

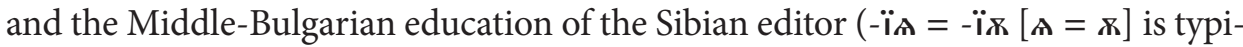
cal of Bulgarian Slavonic and of all the «sub-types» of the Rumanian one), but also his Moldavian origin ( $\mathrm{A}=\breve{\imath a}$ was typical of Russian, Lituano-Ruthenian and Moldavian Slavonics) ${ }^{71}$. It may also be observed that in the Rumanian text of the SRT, $\boldsymbol{A}$ is confused with both $\mathbf{r}$, $\mathbf{E}$ and $\epsilon / \mathfrak{r}$, a confusion transmitted, respectively, to the Moldavian and Wallachian «sub-types» from the Russian, Lithuano-Ruthenian,

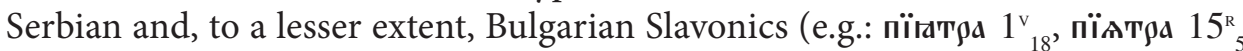

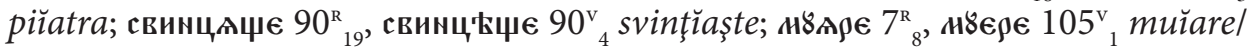

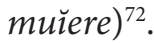

The Rumano-Cyrillic scripta of the SRT registers also numerous cases of $\mathbf{t} \mathbf{(}(\mathbf{w})$ for (i) $\mathbf{n}$ in the inflection of the m. pl. n.-acc., both articled (cf. -ы for -їи, in г'8вавы $27^{\mathrm{R}}{ }_{17}$ and $32^{\mathrm{R}}$, Болнавы $19^{\mathrm{v}}{ }_{1}$, ватрбъныи $111^{\mathrm{R}}{ }_{2}$, спины $42^{\mathrm{R}}$, оүрекбы $43^{\mathrm{R}}$ ) and bare (cf. -ы for -и, in aпís $59_{6}^{\mathrm{v}}$, вєкы $47_{2}^{\mathrm{v}}$ ), and in other cases, where $\mathbf{b l}$ was read

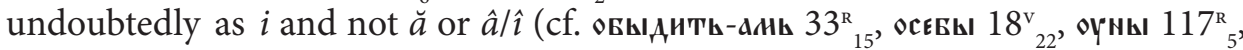

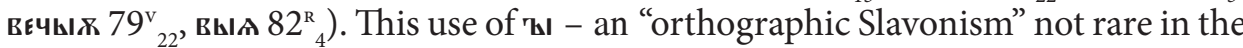
Rumanian and Slavo-Rumanian texts of the $16^{\text {th }}$ century - indicates that who translated and redacted the Rumanian text of the SRT had learned Cyrillic in Serbian or, more likely, Bulgarian, but not Russian or Ruthenian environment (but cf. Psl. $\mathbf{z} \mathbf{l}=$ r. $y$, Ucr. $y / i$ ), which could also mean Wallachian or Moldavian ${ }^{73}$. Due to the influence of Lituano-Ruthenian and Russian Slavonic, started in the $15^{\text {th }}$ century, the Rumanisms contained in Moldo-Slavonic documents often assign to yeryi the value of a central vowel - confusing it with $\boldsymbol{x}$ and $\mathbf{h}$, not with $\mathbf{n}-$ and the same situation occurs later, in the Moldavian scriptee of Rumanian ${ }^{74}$. Moreover, the influence of the Euthymian tradition on the Moldavian scriptoria prevents us from drawing a frontier line based on the Middle Bulgarian and "southern" use of the 'tl, placing the redaction of the SRT on either side of it ${ }^{75}$.

Compared to the orthography, the mould of the Slavonic lexicon of the Rumanian text gets even more complicated, with terms ascribable to different Slavonics

\footnotetext{
${ }^{71}$ Cf. L. Djamo-Diaconiță, Redacțiile slavonei, [in:] Slava veche și slavona românească, ed. P. OlteANU, București 1975, p. 245, 253, 263.

${ }^{72}$ Cf. Ibidem, p. 267.

${ }^{73}$ Cf. I. BĂRBULESCU, Fonetica alfabetului chirilic în textele române din vécul XVI și XVII în legătură cu monumentele paleo-, sîrbo-, bulgaro-, ruso- și româno-slave, Bucuresci 1904, p. 345-363.

${ }^{74}$ About the use of $\mathbf{m}$ ( $\mathbf{m}$ ) in the Rumanian environment, cf. L. DJAmo-Diaconiţă, Limba documentelor slavo-române emise în Ţara Românească în sec. XIV și XV, București 1971, p. 73-74 and G. MIHĂILĂ, Grafia cuvintelor românești, [in:] Dicţionar al limbii române vechi. Sfârșitul sec. X - începutul sec. XVI, București 1974, p. 187.

${ }^{75}$ The same use of 'bl can be found in the Rumanian Tetraevangelion of Coresi, edited with the contribution of Șchei belonging to the Orthodox Transylvanian low clergy. Cf. Tetraevanghelul tipărit de Coresi (Brașov 1560-1561), comparat cu Evangheliarul lui Radu de la Mănicești (1574), ed. F. DimITRESCU, București 1963 (cetera: CRT), p. 32, 40, 58, 60, 61, 76, 85, 124, 127, 136, 167.
} 
and uses of Slavonic but, above all, common to Slavonic and emerging vernaculars (Slavic and naturally Rumanian).

The Rumanian text of the SRT contains a significant number of erudite Slavonisms, which cannot be found either in the Slavonic parallel text of the SRT, the SST, the Trg, or in the oldest Church Slavonic tradition of the Gospel of Matthew (with the exception of a handful of versions from the Eastern-Slavonic area, cf. EMST). These are crude or little acclimated loans, ascribable not only to ecclesiastical (if not properly biblical) ${ }^{76}$ lexicon but also to the chancery one or to both ${ }^{77}$. The most characterizing are common Slavonisms - in some cases, rather words from Slavic vernaculars - with an equally low level of Rumanian acclimation, whose origins are yet to be studied in detail ${ }^{78}$.

See the list of salient cases, with a description of influences (Slavic and nonSlavic) that they might have been exposed to and a comparison to the most relevant versions of the Gospel of Matthew, provided below ${ }^{79}$ :

\section{1. талгы tă̆ag 'stick' $27^{\mathrm{v}}{ }_{8}$ hap. - Mt 10, 10}

SRT-Sl, CST жєзль; EMST жъъдл'ъ; CRT толги; Sept Stecken; Ment Rüte; Ol holi; etym.: Ch. Sl. тоrard, -r - cf. Bg. тояг $(a)^{80}$;

It is clearly a Bulgarism - of even Proto-Bulgarian origins - but with a certain literary tradition in Church Slavonic sources also of Eastern-Slavonic redaction. It displays a peculiar case of akan'e $(o>a)$ maybe Ruthenian, Russian or dialectal Bulgarian (in Bulgarian, this phenomenon is limited to the most conservative dialects, such as dialect of Rodopi or of Șchei in Transylvania) ${ }^{81}$.

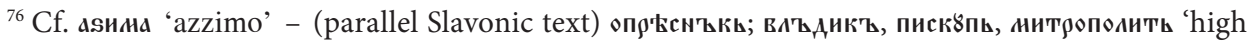

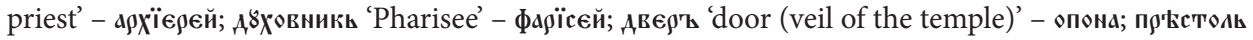

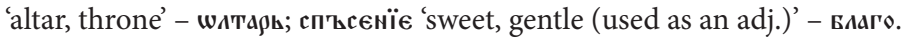

${ }_{77}$ Cf. чїнь 'order, kind' - пшль; даждє 'duty' - кинось; слова 'letter' - Іштта; титта 'sign' - чрьта; ваттахь

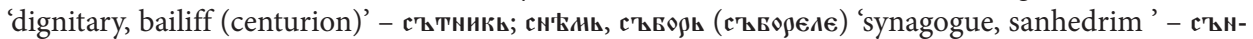
мичє, с'ънинь.

${ }^{78}$ Cf. Г.П. КлеПиковА, Наблюдения над тексикой румынских переводов славяно-румынских текстов конфессионального характера (XVI-XVII вв.), [in:] Folia Slavistica Рале Михайловне Цейтлин, еd. А.Ф. ЖурАвлев, Москва 2000, р. 59-60.

${ }^{79}$ In addition to the Slavonic parallel text (SRT-sl), the Rumanian SRT text will be compared to other 8 versions of the Gospel of Matthew, 3 of which have never been mentioned sofar: Paleoslavic tradition of the Gospel of Matthew, Septembertestament of Luther (1522), Mentelin Bibel (1466) and Czech Olomoucká Bible (1417). Cf. M. Luther, Die Septemberbibel. Das Neue Testament deutsch von Martin Luther, Berlin 1883 (cetera: Sept); Die erste deutsche Bibel, vol. I, Evangelien, ed. W. Kurrelmeyer, Tübingen 1904 (cetera: Ment); Olomoucká Bible, SVKOl M III1/II (cetera: Ol). For the Greek and Latin text of the NT, cf. https://www.academic-bible.com/en/home [1 III 2019].

${ }^{80}$ Cf. F. MiкLosich, Lexicon Linguae Palaeoslovenico-Graeco-Latinum. Emendatum Auctum, Vindobonae 1862-1865, p. 998; Lexicon Linguae Palaeoslovenicae. Slovník Jazyka Staroslověnskeho, vol. XLIII, Praha 1990, p. 479; Н. Геровъ, Ръчник на блъгарскый языкъ, vol. V, Пловдивъ 1904, р. 349.

${ }^{81}$ С.. В.И. ГЕоргиев, Русское аканье и его отнотение к системе фонем праславянского языка, ВЯ 12, 2, 1963, p. 26-27 (F. MiкLośich, Die Sprache der Bulgaren in Siebenbürgen, DKAW.PhH 7, 1856, p. 23, 36).
} 


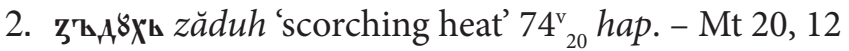

SRT-Sl, CST варь; EMST варъъ; CRT здаяоүхь; Sept Hytze; Ment Hitze; Ol horko;

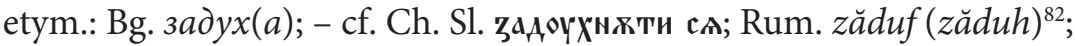

Maybe originally a "living" Bulgarism. Not attested in Paleoslavic, it cannot be, however, classified as a literary Slavonism. It shows a typical sign of Rumanian acclimation such as closing

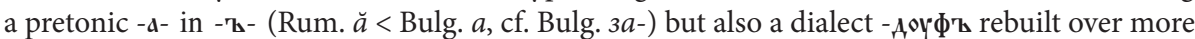
literary and "more Bulgarian" -

3. Ав хуовничи duhovnici 'Pharisees (priests)' $25_{22}^{\mathrm{v}}, 69^{\mathrm{v}}{ }_{14} \ldots-$ Mt 9, 34; 19,3 and passim SRT-Sl фарїсєиє; EMST фаристи; CRT фарисєи; Sept, Ment Pharifeer; Ol dhucownyczi;

etym.: Ch. Sl. доуховьник'ь - cf. Pol. duchownych and C. duchovník 'Pharisee, religious (Latin priest) ${ }^{34}$;

The attestation of Aоуховьникь can be found in Church Slavonic at least from the $14^{\text {th }}$ century in Serbian area, in the $15^{\text {th }}$ in Lithuano-Ruthenian and Russian areas, with the meaning of 'theologian' («veniæ divinæ interpres») and 'priest, parish priest" ${ }^{85}$, more than enough to make the SRT use of the word "heretic" with the meaning of "Pharisee" (see above). It remains probable, however, that the this last - with which Slavo-Rumanian voice has never been attested ${ }^{86}$ - derives from the contribution of Polish and, above all, Czech, where the word is recorded in several sources of the same centuries, meaning not only 'interpreter of the Mosaic Law, Pharisee, Hebraic priest', but 'Latin priest' too.

4. гонине grivne 'talents, silver coins', $67^{\mathrm{v}}{ }_{17}$ hap. - Mt 18, 24

SRT-Sl, TCS талантьь; EMST талан'ът'ы 'talents'; CRT соли 'sommi'; Sept, Ment Pfundt 'talents (value of equivalent weight in silver or gold'); Ol záwazzij [cf. závažie];

${ }^{82}$ Н. Геровъ, Ръчник..., vol. II, Пловдивъ 1897, p. 68; Старобългарски речник, vol. I, София 1999, p. 515; DEXonline: zăduf (zăduh), https://dexonline.ro/definitie/zaduh [14 I 2019].

${ }^{83}$ Cf. E. Petrovici, Note slavo-române III, D 11, 1948, p. 192; G. MiнĂILĂ, Imprumuturi vechi sudslave în limba romînă. Studiu lexico-semantic, București 1960, p. 106.

${ }^{84}$ Cf. Vokabuláŕ webový: duchovník, http://vokabular.ujc.cas.cz/hledani.aspx [13 I 2019]; IBL Słownik Polszczyzny XVI wieku: duchownik, https://spxvi.edu.pl/indeks/haslo/50 060 [20 I 2019]; Stownik staropolski, ed. S. UrbaŃczyк, vol. II.3, Wrocław-Kraków-Warszawa 1957, p. 219; P. Sкок, La terminologie chrétienne en slave: l'église, les prêtres et les fidèles, RES 7, 3, 1927, p. 189.

${ }^{85}$ Cf. F. MiкLosich, Lexicon..., p. 182; Ђ. ДАничић, Рјечник из книжевних старина српских, vol. I, Биоград 1863-1864, p. 318-319; Словник Староукраїнської Мови XIV-XV cm., vol. I, Київ 1971, p. 332; Гістарычны Слоўнік Беларускай Мовы, vol. IX, Минск 1989, p. 107 and Словарь русского языка XI-XVII вв., еd. В.В. Виноградов еt al., vol. IV, Москва 1977, p. 381-382.

${ }^{86}$ In Rumanian, duhovnic is attested since the $17^{\text {th }}$ century with the meaning of 'confessor'. Cf. H. TiKTIN, Rumänisch-Deutsches Wörterbuch, vol. II, Cluj-Napoca 2003 [1911], p. 116; Dicţionarul Limbii Române, s.n., vol. I.6, București 2009, p. 982-984; I. PopincEAnu, Religion, Glaube und Aberglaube in der Rumänischen Sprache, Nürneberg 1964, p. 151. 
etym.: Ch. Sl. грывьна - cf. Pol. grzywna and C. grivna, hrzyvna ${ }^{87}$;

Densusianu records it in the $16^{\text {th }}$ century as «ancienne monnaie (marc)» ${ }^{88}$. In Rumanian, гривн'ъ entered by means of Moldo-Slavonic, where it was firstly attested in 1408 (the first time in Wallacho-Slavonic not earlier than 1544) ${ }^{89}$, but it derives from гянв(к)на (гяывна), that is Lithuano-Ruthenian and Russian Slavonic ${ }^{90}$, if not directly from Polish or Czech vernacular (the Polish grzywna was the most familiar among Rumanians, especially in Moldavia) ${ }^{91}$.

5. нъъка тӑzca 'sap' $97^{\mathrm{R}}{ }_{1}$ hap. - Mt 24, 32

SRT-Sl, CST въа; EMST въъ; CRT стєьлєлє steblele; Sept Tzweyg; Ment Aff; Ol vietew;

etim.: Bulg. мъзга (cf. Sl. eccl. нћзга; r. мпззга; Ser. мезг[p]a; Pol. miazga) and Rum. $m \hat{a} z c \breve{a}^{92}$;

It is the Bulgarian form of Ch. Sl. н'\$зга ' juice, sap', with Saxon unvoicement of the velar $(-g->-k-)$. In the Rumanian text of the SRT, the word "branch" is missing (cf. GNT UBS 5 k $\lambda \dot{\alpha} \delta \circ$, Vulg ramus). The sentence «when the branch [of the fig-tree] becomes tender» was curiously replaced

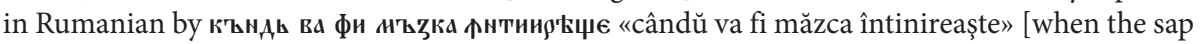
will make it tender (the fig-tree)], which does not match neither with the Slavonic parallel text, nor with any other version of the Gospel of Matthew likely to have influenced the Rumanian version of the SRT ${ }^{93}$. Only in Sept the branch of the fig-tree "becomes succulent" («wenn feyn

${ }^{87}$ Cf. Словник Староукраїнської..., vol. I, p. 262; Гістарычны Слоўнік Беларускай..., vol. VII, Минск 1986, р. 159; И.И. СрезневСкий, Матералы для Словаря древне-русскаго языка по письменнымъ памятникамъ, vol. I, С.-Петербургъ 1893, p. 590; F. SŁAWsкI, Stownik etymologiczny języka polskiego, pars 4, Kraków 1955, p. 374-375; Słownik staropolski..., vol. II.7, p. 517-520; Vokabulár webový: grivna (hrzyvna) [14 I 2019].

${ }^{88}$ O. Densusianu, Opere, vol. II, Lingvistica: Histoire de la langue roumaine, București 1975 [1938], p. 809.

${ }^{89}$ Cf. G. Bolocan, Dicționarul elementelor românești din documentele slavoromâne, 1374-1600, București 1981, p. 98; Dicţionarul Limbii Române, vol. II.1, ed. S. PuşCARIIU, București 1934, p. 314-315. ${ }^{90}$ Actually, the Sl. есcl. грив(ь)на was attested from the beginning of the $11^{\text {th }}$ century in sources of Russian-Kevian and Czech-Moravian redaction (the latter [i.e. Gregory the Great's XL Homilice in Evangelia] were originated in the Bohemian area, but are preserved in Russian copies from the $13^{\text {th }}$ and $14^{\text {th }}$ centuries, cf. F. Miklosich, Lexicon..., p. 143; Lexicon Linguae Palaeoslovenicae..., vol. VIII, Praha 1964, p. 434 and И.И. Срезневский, Матеральь.., vol. I, p. 589-591).

${ }^{91}$ Cf. A. MAREş, Echivalările Talantului în textele româneşti din secolele al XVI-lea şi al XVII-lea, LR 49, 3, 2000, p. 483-484.

${ }_{92}$ Cf. F. MiкLosich, Lexicon..., p. 123-124; Български етимологчен речник, vol. IV, еd. В.И. Георгиев, София 1995, p. 379; Dicţionarul Limbii Române, s.n., vol. XVII.6, Bucureşti 1968, p. 735-736.

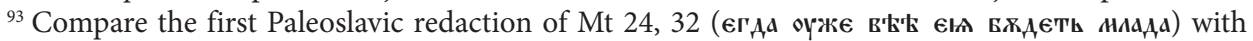
the Czech version of Olomoucká Bible ( «když již vietew jeho miekká»), the Hungarian version of the so-called Huszita Biblia (1425 ca.), copied in Moldavia in 1466 («mikor ő ága meggyermekdedölend») and the Polish version of Murzynowski (1551), inspired by the Lutheran tradition («Gdy by już gałąź jéj zstała się młodocianą»). The word "branch" is written in italics in every quotation. Cf. Ol, f. 182 ${ }_{47}^{\mathrm{vB}}$; A Müncheni kódex (1466). A négy Evangélium szövege és szótára [Huszita Biblia], ed. G. DÉcsi, T. Szabó, Békéscsaba 1985, p. 87; Evangelia Svvieta pana Iesusa Christusa Vedle Mathoufza Svietego z Greckiego Iezyka na Polski przelozona [przez S. Murzynowskiego]..., w Krolewcu Prufkim 1551, f. $94_{2-3}^{\mathrm{v}}$. 
tzweyg itzt fafftig wirt» $)^{94}$. The Lutheran text remains, indeed, the only comparable to the Sibian as for the translation of Mt $24,32^{95}$.

6. авновнї̈ lunovnїа о -їe, 'epileptics, somnambulists (lunatics)' $3^{\mathrm{v}}{ }_{22}$ hap. - Mt 4, 24

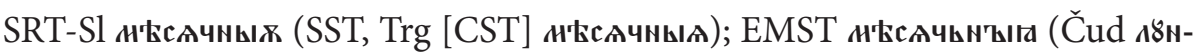
ств8ющағ); CRT дљжчици пює А४ни drăciţi pre luni 'possessed at every new moon'; Sept, Ment Monfuchtigen; Ol namiefiecznyki;

etym.: Ch. Sl. лоүновн'ыи? (лоүновьн'ъ, лоүнав'ъ) - cf. Ch. Sl. лоүн(ств)овати ся 'suffer from lunatism (somnambulism or epilepsy)', лүнстввюючий (лүнүючий ся) 'lunatic, possessed, epileptic', лоүновєнию 'menses'; Pol. lunatyk 'lunatic, epileptic ${ }^{96}$;

It's clearly a calque after the Ch. Sl. лоүновн'ын, the pl. acc. of an adj. лоүновн'ыи and pronominal form of лоүновьн'ъ (Rum. *lunоvпй). Interestingly, the Sibian revision seems to have overlooked this word, though it's perfectly Slavic: 1 . The suffix -ïn -ǐe for Rumanian m. pl. acc. suggests a typographical error, though it is but a slight adjustment of the Church Slavonic adjectival suffix

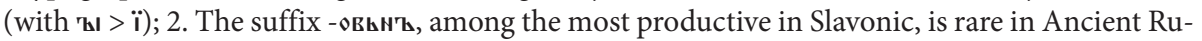
manian (we only find it in the adj. слоновн'ъ slonоvпй 'ivory" < слоновьн'ъ, an "exоtic" Slavonism, in the late $16^{\text {th }}$ century $)^{97} ; 3$. The same stem luna- is, in fact, no less Slavic than Latin ${ }^{98}$. In the

${ }^{94}$ Sept, p. 20 (cf. also Biblia: das ist die gantze Heilige Schrifft Deudsch auffs New zugericht. D. Mart. Luth.... Gedrückt zu Wittemberg: Hans Lufft, 1541 [cetera: Lut]), f. $259^{\mathrm{v}}{ }_{43}$.

${ }^{95}$ Luther's Bible registers an adj. safftig only in Mt 24, 32, the corresponding noun Saft 'sap (vital $=$ lymph [also fig.])' in different settings and, especially, in Lc 8, 6 (in the Parable of a sower [cf. Mt 13, 5]: und ettlichs [famen] fiel auff den fels und da es aufgieng verdorret es darumb das nicht fafft hatte...). Saft appears, however, more often in the sermons of Luther and, above all, in the locution Saft und Kraft 'quinta essentia (fünfte Wesen)', where the fig-tree is explicitly identified with the Holy Scriptures made fruitful thanks to the incarnation of the Word. Cf. M. Luther, Saemmtliche Werke, vol. X, Kirchenpostille, ed. G. Plochmann, Erlangen 1827, p. 78; DWB: http://www.woerterbuchnetz.de/DWB?lemma=saft [25 II 2019]; Sept, p. 42 (Lut, f. $231_{16}^{\mathrm{R}}$ ).

${ }^{96}$ Cf. F. MiкLosich, Lexicon..., p. 344; П.Д. Филкова, Староболгаризмы и церковнославянизмы в тексике русского титературного языка. Учебный словарь, vol. II, София 1986, p. 591 and Словарь русского языка..., vol. VIII, Москва 1981, p. 306; IBL Słownik Polszczyzny XVI wieku: lunatyk, https://spxvi.edu.pl/indeks/haslo/62 455 [20 I 2019]; about the Czech tradition, http://vokabular. ujc.cas.cz/hledani.aspx [28 II 2019].

${ }^{97}$ More specifically, слшнювнилюя slonovnilor [made of ivory], in several versions of Sal 44, 9. Cf. Psaltirea Şcheiană comparată cu celelalte psaltiri din sec. XVI și XVII traduse din slavonește, vol. II, Textul şi glosarele, ed. I.-A. Candrea, București 1916, p. 87; O. Densusianu, Opere, vol. II..., p. 826 (the suff. -овьн'ъ is attested at least 22 times in the Paleoslavic canon, cf. Z. Ribarova, Indexy k staroslověnskému slovníku, Praha 2003, p. 168).

${ }^{98}$ It is believed that Sl. ${ }^{*} l u n a ́-$ and Lat. lüna- (proto-it. *louksnā-) are independent outcomes of the proto- i.e. ${ }^{*} l o u k-s-n e h_{2}$ 'luminous, resplendent'. Naturally, that does not affect the possibility of a reciprocal influence between the outcomes of the two stems in contact areas. Cf. H. MiнĂESCU, La romanité dans le Sud-Est de l'Europe, Bucureşti 1993, p. 451-453; Этимологический словарь славянских языков. Праславянский тексический фонд, еd. О.П. ТруьАчев, vol. XVI, Moсква 1990, p. 173-174; M. DE VAAN, Etymological Dictionary of Latin and the other Italic Languages, Leiden-Boston 2008, p. 352; R. Derksen, Etymological Dictionary of the Slavic Inherited Lexi- 
Coresian corpus, a popular belief that associated epilepsy with lunatism led to various terminological outcomes, but no exact equivalent of "lunatic"99. The only relatable word in Rumanian seems to be lunovnie until the second quarter of the $17^{\text {th }}$ century, when А чи lunateci appeared in ecclesiastical sources ${ }^{100}$. Unlike *lunovnŭ, lunav and lunatec already were Rumanian, at least virtually: 1 . since they already used suffixes which were productive in Ancient Rumanian ${ }^{101} ; 2$. lunatec is considered to be an inherited Latinism (cf. zănatec $<$ lat. dianaticus 'insane [due to the influence of Diana i.e. of the Moon]', therefore 'possessed, enchanted by a zână, cf. Rum. zână 'fairy' < Lat. Diana $)^{102}$. It's a fact that lunav and lunatec are attested in Rumanian

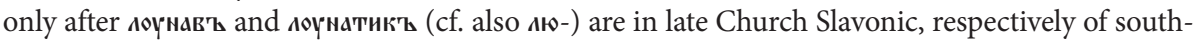
ern and eastern redaction ${ }^{103}$. Emblematic is the case of lunatec, which will enter the literary Rumanian language at its early stage thanks to the influence of educated Latin ${ }^{104}$, directly or via Ruthenian ${ }^{105}$ and/or Polish ${ }^{106}$. We can suppose that about a century before, ${ }^{*} l u n o v n u ̆$ had been

con, Leiden-Boston 2008, p. 291 (about the influence of other similar suffixes in the Slavic area, cf. also Л.В. Куркина, Славянские этимологии (*luna, ${ }^{*} l u n ' a,{ }^{*}$ setønzjь u ${ }^{*}$ sotiti, ${ }^{*}$ stopвnzkz, ${ }^{*}$ telm-,

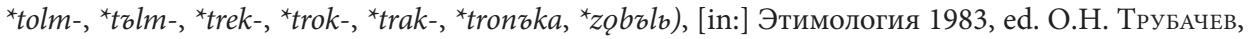
Москва 1985, p. 20-21).

${ }^{99}$ It is not irrelevant that the CRT restricts the meaning of "lunatic" to "possessed" (cf. Алжчици пює А४ни drăciţi pre luni). Coresi’s Cazanie II (1581) - an homiletic text - renders, by apparently current Old Rumanian words, as "lunaticism" (лоүнїє lunïe, Бодлж дєф моүнж boală den lună 'moon sick-

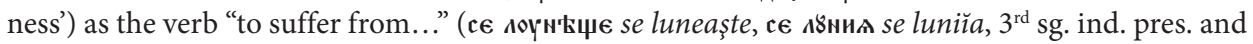

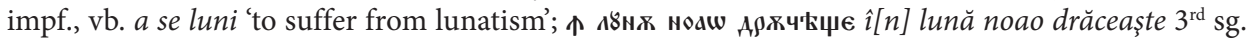
ind. pres., vb. a drăci în lună nouă 'to display possession at the new moon'). Cf. CRT, p. 43 [f. $6^{\mathrm{v}}{ }_{5}$ ]; Carte cu învăţătură (1581), vol. I, Textu, ed. S. PuşCariu, A. Procopovici, București 1914, p. 271, 273-276 (CR XVI V 1 BNR, ff. 69R $-71^{\mathrm{R}}$ ).

${ }^{100}$ Respectively, Lunav in Metropolitan Varlaam's Cazanie (1643) and lunatec in the Nou Testament de la Bălgrad (1648). Cf. VarlaAm, Cazanie 1643, ed. J. BYcK, București 1966, p. 153 (CR-XVII-V-2 BNR, f. $220^{\mathrm{R}}{ }_{5}$; Noul Testament sau Înpăcarea, sau Leagea Noao a lui Iisus Hristos..., Bălgrad [Alba Iulia] 1648 (cetera: NTB), f. $6^{\mathrm{R}}{ }_{28}$.

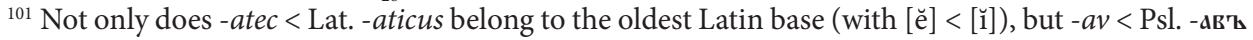
- being also attested in Arumanian - can be dated back before the early $12^{\text {th }}$ century. Cf. G. PASCU, Sufixele româneşti, Bucureşti 1916, p. 99-103, 281-292.

${ }_{102}$ Cf. H. MihĂESCU, La romanité..., p. 178, 451 (B.-P. HAşDEU, Eymologicum magnum Romanić, vol. I.2, Bucuresci 1887, p. 2046-2049).

${ }^{103}$ In fact, Ch. Sl. моүнав' is so late and scarcely attested - it was recorded only by Miklošič, in Serbian $16^{\text {th }}$ century sources - that we can realistically suppose it reflected in Varlaam an older Southern-Slavonic and Rumanian use.

${ }^{104}$ From the NTB to the Biblie de la Blaj (1795), through the Biblie de la București (1688) and Antim Ivireanu's Nou Testament (1703), all Rumanian versions of Mt 4, 24 - originally based on the Vulgata - contain lunateci. Cf. Biblia adecă Dumnezeiasca Scriptură..., București 1688, p. 753; Noul Testament acum $\hat{\imath}(n)$ tăi tipărit..., București 1703, f. $3_{4}^{\mathrm{v}}$; Biblia adecă Dumnezeiasca Scriptură..., Blaj 1795 , p. $4^{\mathrm{B}}{ }_{44^{\circ}}$.

${ }^{105}$ Pamvo Berinda (1627) translated the Ch. Sl. Аภнлчїй сл with Rut. люнаттїкь, which Mardarie Cozianul (1649) translated in turn with Rum. А४натєкь. Cf. П. БЕРиндА, Лексіконб славеноросскій и именъ Тълкованїe, Київ 1961, p. 59; MaRdarie Cozianul, Lexicon slavo-românesc și tâlcuirea numelor din 1649, ed. G. Creţu, Bucuresci 1900, p. 167.

${ }^{106}$ Pol. lunatyk, attested since 1528, appears in the first versions of the Gospel of Matthew - translated and printed by two Lutherans, Murzynowski and Jan Seklucjan (1551 and 1553) - and in 9 out of 10 Polish versions appeared between 1551 and 1599 (only in the Calvinist version of the Biblia Brzeska 
considered an erudite approximation to the terms in use for "lunatic (epileptic)". Nonetheless, it was such an unusual Slavonism that who had translated and revised the Rumanian text of the SRT inflected it, mechanically, as it was Slavonic ${ }^{107}$. The reasons of this choice could be two: 1. more vernacular alternatives such as drăciţi (pre luni) or zănateci would have caused a re-

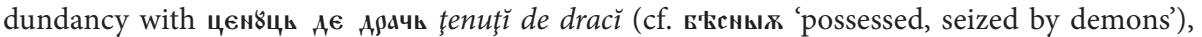
which preceded lunovnïe in the same list of infirms ${ }^{108}$; 2 . lunateci was likely to sound too "Latin" (i.e. Western Christian), attracting on the text suspicions of heterodoxy (whence the choice of this uncommon but formerly "Slavonizing" translation).

The Slav(on)isms found in the Rumanian text of the SRT seem to reflect an area of transition and overlapping between the diverse Slavias as well as between Slavia and Romània (the crossing of all the mentioned influences being the most original trait of what - reducing in scale, and using very lato sensu, the key-concept of Slavia orthodoxa - we can call Slavia valachica [i.e. Rumanian Slavia]).

The Old Rumanian of the SRT reflects, however, another boundary, apparently not less labile of the geographical one and wholly internal to Slavia Orthodoxa, between two different spheres of use of the Slavonic language: the one cultivated, only primarily ecclesiastical and strongly ingrained in the Euthymian tradition, the other semi-cultivated, more immediately linked to the practical uses (chancery, private, but also literary-popular) and open, therefore, to a koเvi of vernacular languages which varied, partially, according to the zone (Dobrev ${ }^{109}$ compared this difference to that between sanscrit and pracrits, and assigned the Slavonics in use in the Peri-Danubian and Transylvanian areas a paradigmatic role).

Evidently, a "multiple boundary" which crosses the SRT unites the two texts, Slavonic and Rumanian, rather than divides them, fixing them - not only metaphorically, as a whole - to an extraordinary crossroad of different epochs and influences.

[1556] miesięcznik appears). At the end of the $16^{\text {th }}$ century, Jakub Wujek's Catholic version (1593 and 1599) still glossed lunatyki with miesiącziki, in the translation of Mt 4, 24 («lunátykowie fą co káduk miewáią» [lunatics are those who suffer from falling sickness]). Cf. Polish versions of the Gospel at https://ewangelie.uw.edu.pl/teksty? $\mathrm{y}=\mathrm{all} \& \mathrm{~g}=1 \& \mathrm{c}=4 \& \mathrm{v}=24$ [29 I 2019]; the note in Nowy Testament Pana Naszego Jesusa Chrystusa Znowu $z$ łacińskiego y z greckiego na polskie wiernie i szczyrze przełożony... przez D. Jakuba Wuyka, Kraków 1593, p. 15 and 1599, p. 14.

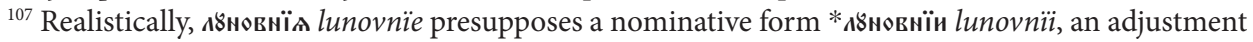
to the Middle Bulgarian spelling of the literary лоүновн'ыи. It can be assumed that the Rumanian pl. acc. А 8 новнты(и) оr 18 новн(ї)и lunovnïi may have been confused with the homonymous and virtually homophone sg. acc. pronominal Slavonic form, wrongly amended by the Sibian revisor, since the

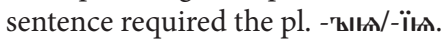

${ }^{108}$ It is worth noticing that in the CRT it does not occur, because the sentence was translated in a different way: «şi aduseră lui toţi bolnaviii de toate boale şi de chinure ţinuţi şi drăciţi pre luni...» (cf. SRT-Rum: «şă aducea lui toţŭ bolnavi în multe chipure bòlele şă cu chinure ţenuţĭ de dracĭ şă

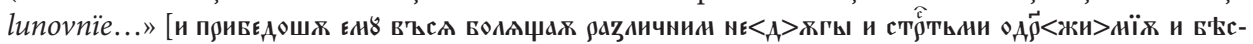

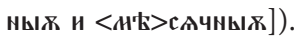

${ }^{109} \mathrm{Cf}$. И. Доврев, XIV век - Класицизьм или пракрити?, [in:] Преводи през XIV столетие на Балканите. Доклади от международната конференция. София, 26-28 юни 2003, еd. Л. ТАсЕвА et al., София 2004, p. 17-19. 


\section{Bibliography}

\section{Primary Sources}

A Müncheni kódex (1466). A négy Evangélium szövege és szótára [Huszita Biblia], ed. G. DÉcsI, T. Szabó, Békéscsaba 1985.

Acte si fragmente latine romanesci pentru istori' a Beserecei romane mai alesu unite, edite si adnotate, ed. T. Cipariu, Blasiu 1855.

BERINDA P., Leksikon" slavenorosskij i imen" tl"kovanïe, Kyïv 1961 [1627].

Biblia adecă Dumnezeiasca Scriptură..., Blaj 1795.

Biblia adecă Dumnezeiasca Scriptură..., București 1688.

Biblia: das ist die gantze Heilige Schrifft Deudsch auffs New zugericht. D. Mart. Luth... Gedrückt zu Wittemberg: Hans Lufft, 1541.

Carte cu învăţătură (1581), vol. I, Textu, ed. S. PușCariu, A. Procopovici, București 1914 (= CR XVI V 1 BNR).

Codicele Bratul, ed. A. GAFton, Iaşi 2003 (= http://media.lit.uaic.ro/gafton/txt/text).

Die erste deutsche Bibel, vol. I, Evangelien, ed. W. Kurrelmeyer, Tübingen 1904.

Evangelia Svvieta pana Iesusa Christusa Vedle Mathœufza Svietego z Greckiego Iezyka na Polski przelozona [przez S. Murzynowskiego]..., w Krolewcu Prufkim 1551.

Evangelie ot Matfeja v slavjanskoj tradicii, ed. A.A. Alekseev, A.A. Pičchadze et al., Sankt-Peterburg 2005.

Evangheliarul slavo-român de la Sibiu (1551-1553), ed. E. Petrovici, L. Demény, Bucureşti 1971.

Liturghier slavonesc lui Macarie, Târgovişte 1508 - BAR II 170567.

Luther M., Predigt am vierten Sonntage nach Epiphanias, [in:] Hauspostille, vol. II, ed. J.G. PLochMANN, Erlangen 1826.

Luther M., Saemmtliche Werke, vol. X, Kirchenpostille, ed. G. Plochmann, Erlangen 1827.

Luther M., Die Septemberbibel. Das Neue Testament deutsch von Martin Luther, Berlin 1883.

Mardarie Cozianul, Lexicon slavo-românesc și tâlcuirea numelor din 1649, ed. G. Creţu, Bucuresci 1900 .

Noul Testament acum î(n)tăi tipărit..., București 1703.

Noul Testament sau Înpăcarea, sau Leagea Noao a lui Iisus Hristos..., Bălgrad [Alba Iulia] 1648.

Nowy Testament Pana Naszego Jesusa Chrystusa Znowu z łacińskiego y z greckiego na polskie wiernie i szczyrze przełożony... przez D. Jakuba Wuyka, Kraków 1593.

Octoih slavonesc lui Macarie, Târgovişte 1510 - BAR II 630846.

Olomoucká Bible, SVKOI M III1/II.

Psaltirea Șcheiană comparată cu celelalte psaltiri din sec. XVI și XVII traduse din slavonește, vol. II, Textul și glosarele, ed. I.-A. CANDrea, București 1916.

Ribarova Z., Indexy k staroslověnskému slovníku, Praha 2003.

Szesnastowieczne przekłady Ewangelii: https://ewangelie.uw.edu.pl/teksty? $\mathrm{y}=\mathrm{all} \& \mathrm{~g}=1 \& \mathrm{c}=4 \& \mathrm{v}=24$

Das Tetraevangelium des Makarije aus dem Jahre 1512. Der $1^{\text {te }}$ kirchenslavische Evangeliendruck. Faksimile-Ausgabe, ed. H. Miklas et al., Padeborn-München-Wien-Zürich 1999.

Tetraevanghel slavonesc, Sibiu 1546, BAR II 630838. 
Tetraevanghel slavonesc lui Coresi, Braşov 1562, BAR III 234272.

Tetraevanghel slavonesc lui Lavrentie, Plumbuita 1575 ca., BCU-Cluj BRV 34.

Tetraevanghelul tipărit de Coresi (Brașov 1560-1561), comparat cu Evangheliarul lui Radu de la Mănicești (1574), ed. F. Dimitrescu, București 1963.

VArlaAm, Cazanie 1643, ed. J. Byck, Bucureşti 1966 (= CR-XVII-V-2 BNR).

\section{Lexicons and Dictionaries}

Bălgarski etimologičen rečnik, vol. I-VIII, ed. V.I. GeorgIEv, Sofija 1971-2017.

Bolocan G., Dicționarul elementelor românești din documentele slavoromâne, 1374-1600, București 1981.

DANIČIĆ Đ., Rječnik iz književnih starina srpskih, vol. I-III, Biograd 1863-1864.

DE VAAn M., Etymological Dictionary of Latin and the other Italic Languages, Leiden-Boston 2008.

Derksen R., Etymological Dictionary of the Slavic Inherited Lexicon, Leiden-Boston 2008.

DEXOnline: https://dexonline.ro (= Dicționar Explicativ al Limbii Române (DEX), București 1996).

Dicţionarul Limbii Române (DA), vol. I-III, ed. S. PuşCARIIU, Bucureşti 1913-1940.

Dicţionarul Limbii Române (DLR), s.n., vol. I-XIV, Bucureşti 1965-2000.

DWB: http://www.woerterbuchnetz.de

Ėtimologičeskij slovar' slavjanskich jazykov. Praslavjanskij leksičeskij fond, ed. O.P. TRUBAČEv, vol. I-XLI, Moskva 1974-2018.

Filkova P.D., Starobolgarizmy i cerkovnoslavjanizmy v leksike russkogo literaturnogo jazyka. Učebnyj slovar, vol. I-III, Sofija 1986.

Gerov N., Rěčnik na blăgarskyj jazyk, vol. I-V, Plovdiv 1895-1904.

Gistaryčny Sloŭnik Belaruskaj Movy, vol. I-XX, Minsk 1982-2002.

HaşDeu B.-P., Eymologicum magnum Romaniœe, vol. I-IV, Bucuresci 1887-1898.

IBL Słownik Polszczyzny XVI wieku: https://spxvi.edu.pl

Lexicon Linguae Palaeoslovenicae. Slovník Jazyka Staroslověnskeho, vol. I-LII, Praha 1958-1997.

MiнĂILĂ G., Dicţionar al limbii române vechi. Sfârșitul sec. X - începutul sec. XVI, București 1974.

Mıкцоsich F., Lexicon Linguae Palaeoslovenico-Graeco-Latinum. Emendatum Auctum, Vindobonae $1862-1865$.

Popinceanu I., Religion, Glaube und Aberglaube in der Rumänischen Sprache, Nürneberg 1964.

Slovar' russkogo jazyka XI-XVII vv., ed. V.V. Vinogradov et al., vol. I-XXX, Moskva 1975-2015.

Slovnik Staroukraïnskoï Movi XIV-XV st., vol. I-II, Kyïv 1971-1978.

SŁAWsKi F., Słownik etymologiczny języka polskiego, pars 1-5, Kraków 1952-1982.

Stownik staropolski, ed. S. URBAŃcZYK, vol. I-XI, Wrocław-Kraków-Warszawa 1953-2002.

SReZnevskij I.I., Materialy dlja Slovarja drevne-russkago jazyka po pis'mennym" pamjatnikam", vol. I-III, S.-Peterburg 1893-1912.

Starobălgarski Rečnik, vol. I, Sofija 1999.

Tiктім H., Rumänisch-Deutsches Wörterbuch, vol. I-III, Cluj-Napoca 2003-2005 [1895-1925].

Vokabulář webový: http://vokabular.ujc.cas.cz. 


\section{Secondary Literature}

Alberti A., Gli scriptoria moldavi e la tradizione medio-bulgara. Il caso del Vangelo di Elisavetgrad, [in:] Linee di confine. Separazione e processi di integrazione nello spazio culturale slavo, ed. G. Moracci, A. Alberti, Firenze 2013, p. 15-61.

Alzati C., Terra romena tra Oriente e Occidente. Chiese ed etnie nel tardo '500, Milano 1981.

Atanasov P., L'imprimerie en Roumanie et les bulgares de Braşov au XVI' s. (La collaboration culturelle bulgaro-roumaine au XVI ${ }^{e}$ s.), "Études balkaniques. Revue trimestrielle publiée par l'Institut d'études balkaniques près l'Académie bulgare des sciences" 6, 1967, p. 123-139.

BADALIĆ J., Jugoslavica usque ad annum 1600. Bibliographie der südslavischen Frühdrucke, Aureliae Aquensis 1959.

Bainton R.H., The Reformation of the $16^{\text {th }}$ Century, Boston 1952.

BăRbulescu I., Fonetica alfabetului chirilic în textele române din vécul XVI și XVII în legătură cu monumentele paleo-, sîrbo-, bulgaro-, ruso- și româno-slave, Bucuresci 1904.

Binder P., Inceputurile Reformei din Transilvania și Românii din Hunedoara, "Limba Română" 20, 3, 1971, p. 273-276.

Binder P., Huttmann A., Contribuţii la biografie lui Filip Moldoveanul, primul tipograf român. Evoluţia vieţii culturale românești la Sibiu în epoca umanistă, "Limbă și Literatură" 16, 1968, p. $145-174$.

Binder P., Huttmann A., Între istorie și filologie, I. Mediul cultural românesc al Brașovului în epoca coresiană, "Limba Română" 20, 1, 1971, p. 3-20.

Bodogae T., Și totuși prima carte romanească s-a tipărit la Sibiu. Considerații despre Evangheliarul slavo-român din 1551-1553, "Mitropolia Ardealului" 17, 1-2, 1972, p. 82-89.

Bogdan D.P., Contribuţiuni la bibliografia românească veche. Tipărituri dintre anii 1546-1762 necunoscute la noi, București 1938.

Bogdan I., O Evanghelie slavonă cu traducere română din secolul al XVI-lea, "Convorbiri literare" $25,1,1891$, p. 33-40.

Deletant D., A Survey of Rumanian Presses and Printing in the $16^{\text {th }}$ Century, "The Slavonic and East European Review" 53, 131, 1975, p. 161-174.

Demény L., Cartea și tiparul. Promotori ai legăturilor culturale dintre ţările române în secolul al XVI-lea, "Studii și Materiale de Istorie Medie" 6, 1973, p. 91-109.

Demény L., L'imprimerie cyrillique de Macarios de Valaquie, "Revue Roumaine d'Histoire" 7, 3, 1969, p. 549-574.

Demény L., O tipăritură slavo-română precoresiană, "Studii Revistă de Istorie" 18, 5, 1965, p. 1001-1038.

DemÉny L., Typographische Kennzeichen der kyrillischen Druckerpresse in Hermannstadt im 16. Jahrhundert, "Forschungen zur Volks- und Landeskunde" 19, 1, 1969, p. 25-36.

Demény L., Simonescu D., Un capitol important din vechea cultură românească (Tetraevanghelul, Sibiu 1546), "Studii și Cercetări de Documentare și Bibliologie" 1, Supl., 1965, p. 1-18.

Densusianu O., Opere, vol. II, Lingvistica: Histoire de la langue roumaine, București 1975 [1938].

DJAmo-DiaconițĂ L., Limba documentelor slavo-române emise în Ţara Românească în sec. XIV și XV, București 1971.

Djamo-Diaconiță L., Redacțiile slavonei, [in:] Slava veche și slavona românească, ed. P. Olteanu, București 1975. 
Dobrev I., XIV vek - Klasicizăm ili prakriti?, [in:] Prevodite prez XIV stoletie na Balkanite. Dokladi na meždunarodnata konferencija. Sofija, 26-28 juni 2003, ed. L. TASEva et al., Sofija 2004, p. 17-26.

Dragnev E., O capodoperă a miniaturii din Moldova medievală. Tetraevanghelul de la Elizavetgrad și manuscrisele grupului Parisinus Grćcus 74, Chișinău 2004.

Florescu I.-F., Le Tetraévangile de Sibiu (1551-1553). Nouvelles informations sur les sources de la première traduction en roumain des Evangiles, "Biblicum Jassyense. Romanian Journal for Biblical Philology and Hermeneutcs" 1, 2010, p. 48-89.

Georgiev V.I., Russkoe akan'e i ego otnošenie $k$ sisteme fonem praslavjanskogo jazyka, "Вопросы языкознания" / "Voprosy jazykoznanija” 12, 2, 1963, p. 20-29.

Gherman A.M., Lexic românesc în documente transilvănene. Socotelile orașelor Brașov și Sibiu, "Dacoromania" [s.n.] 13, 1, 2008, p. 57-74.

GHEŢıE I., Baza dialectală a românei literare, București 1975.

GHeţıe I., Consideraţii filologice asupra Evangheliarului din Petersburg, "Studii și Cercetări de Lingvistică" $17,1,1966$, p. 47-79.

GHeţı I., Evangheliarul slavo-român de la Sibiu și textele românești cu litere latine și ortografie maghiară, "Limba Română" 28, 2, 1979.

GHeţıe I., Textele rotacizante și originile scrisului literar românesc. Chestiuni de metodă, [in:] Începuturile scrisului în limba română, București 1974, p. 44-97.

GHeţıE I., [rec.:] Evangheliarul slavo-român de la Sibiu 1551-1553... - "Studii și Cercetări de Lingvistică" 23, 6, 1972, p. 664-670.

Gheţıe I., Mareș A., Originile scrisului In limba română, București 1985.

Hervay F., L'imprimerie du maître Philippe de Nagyszeben et les premiers livres en langue roumaine, "Magyar Könyvszemle" 81, 2, 1965, p. 119-127.

Hurdubeţıu I., Originea Scheilor şi răspîndirea lor pe teritoriul carpato-dunărean, "Studii şi articole de istorie" 14, 1969, p. 195-205.

Iorga N., Cinci comunicări la Academia Română, III, Tipărituri românești necunoscute, "Revista istorică" 17, 1-3, 1931, p. 25-26.

Ivanova D., Pečatnite bălgarski knigi ot XVI vek i starata răkopisna tradicija, “Търновска книжовна школа" / "Tărnovska knižovna škola” 6, 1999, p. 295-311.

Ivanova D., Tărgoviškoto pečatno Evangelie (1512 g.) i starite slavjanskite prevodi na Evangelieto (s ogled na tekstologičnata tradicija), [in:] Bălgaristični proučvanija, vol. I, Veliko Tărnovo 1996, p. $45-60$.

JAKó Z., Szeben latin betüs könyvnyomtatása a XVI. században, [in:] Írás köniv értelmiség, Bukarest 1976.

KARATAEv I.P., Opisanie slavjano-russkich knig, napečatannych kirillovskimi bukvami, "Сборник Отделения русского языка и словесности Академии наук" / "Sbornik Otdelenija russkogo jazyka i slovesnosti Akademii nauk" 34, 2, 1883.

KLePIKova G.P., Nabljudenija nad leksikoj rumynskich perevodov slavjano-rumynskich tekstov konfessional'nogo charaktera (XVI-XVII vv.), [in:] Folia Slavistica Rale Michajlovne Cejtlin, ed. A.F. Žuravliev, Moskva 2000, p. 53-60.

Kurkina L.V., Slavjanskie ètimologii ( ${ }^{*} l u n a,{ }^{*} l u n ' a,{ }^{*}$ set'n"j' $u{ }^{*}$ sotiti, ${ }^{*}$ stop'n" $k$ ", ${ }^{*}$ telm-, ${ }^{*}$ tolm-, ${ }^{*} t^{\prime} l m-$, *trek-, ${ }^{*}$ trok-, ${ }^{*}$ trak-, ${ }^{*}$ tron"ka, ${ }^{*} z Q b$ "'l), [in:] Ėtimologija 1983, ed. O.N. TRUBAČEv, Moskva 1985, p. 20-30. 
MACŮReK J., Husitství v rumunských zemích, “Časopis Matice Moravské” 51, 1927, p. 1-98.

MANolescu R., Cultura orășenească în Moldova în a doua jumătate a secolului al XV-lea, [in:] Cultura moldovenească în timpul lui Ștefan cel Mare, ed. M. BerzA, București 1964, p. 47-95.

Manolescu R., L'écriture latine en Valachie et en Moldavie au Moyen Âge, "Revue Roumaine d'Histoire" 25, 1-2, 1986, p. 59-68.

Mareş A., Echivalările Talantului în textele româneşti din secolele al XVI-lea şi al XVII-lea, "Limba Română" 49, 3, 2000, p. 483-495.

Mareş A., Evangheliarul din Petersburg, tipărirea unei mai vechi traduceri moldovenești, "Limba Română" $17,1,1968$, p. 85-87.

Mareș A., Observaţii cu privire la Evangheliarul din Petersburg, "Limba Română” 16, 1, 1967, p. 65-75.

Mareș A., Originalele primelor traduceri românești ale Tetraevanghelului și Psaltirii, [in:] Scriere și Cultură Românească Veche, București 2005, p. 261-263 (= Cele mai vechi texte românești. Contribuţii filologice și lingvistice, ed. I. GHEŢıE, București 1982, p. 185-187).

Mareș A., Precizări cu privire la traducerea Tetraevanghelului lui Coresi, "Studii și Cercetări de Lingvistică” 18, 6, 1967, p. 652-657.

Mareș A., [rec.] Demény L., L.A. Demény, Carte, tipar și societate la Români în secolul al XVI-lea..., "Limba Română" 27, 5, 1988, p. 477-481.

MÂRzA E., Un fragment din Evangheliarul slavo-român de la Sibiu (1551-1553), "Limba Română" 27, 2, 1978, p. 173-175 (= Explorări bibliografice, Sibiu 2008, p. 14-16).

Medaković D., Grafika srpskih štampanih knjga XV-XVII veka, Beograd 1958.

Mihăescu H., La romanité dans le Sud-Est de l'Europe, Bucureşti 1993.

MiнĂILĂ G., Împrumuturi vechi sud-slave în limba romînă. Studiu lexico-semantic, București 1960.

MıнĂILĂ G., Primul manuscris românesc pre-coresian datat: Codicele Popii Bratul din Braşov (1559-1560) și sursele sale, [in:] Studii de lingvistică și filologie, Timișoara 1981, p. 59-114.

MıнĂILĂ G., Textele bilingve slavo-române și unele aspecte ale studiului calcului lingvistic, [in:] Contribuţii la istoria culturii și literaturii române vechi, București 1972, p. 231-249.

Mıкцоśich F., Die Sprache der Bulgaren in Siebenbürgen, "Denkschriften der kaiserlichen Akademie der Wissenschaften, philosophisch-historische Classe" 7, 1856, p. 105-147.

MiкLośích F., Die Sprache der Bulgaren in Siebenbürgen, Wien 1856.

Miletič L., Dako-Romănitě i těhnata slavjanska pismenost, II, Novi vlaho-bălgarski gramoti ot Brašov, "Сборникъ за народни умотворения, наука и книжнина" / "Sbornik za narodni umotvorenija, nauka i knižnina” 9, 1896, p. 3-152.

MoLIN V., Ilustraţia în vechea carte bisericească, "Biserica Ortodoxă Română" 78, 7-8, 1960, p. 683-719.

Moussakova E., The Illustrated Slavonic Miscellanies of Damascenes Studite's Thesauros - A New Context for Gospel Illustrations in the 17 $7^{\text {th }}$ Century, [in:] Byzantine and Post-Byzantine Art: Crossing Borders, Exploring Boundaries. Art Readings. Thematic Peer-reviewed Annual in Art Studies, vol. I, Old Art, ed. E. Mutafov, I. Toth, Sofija 2017, p. 325-348.

Nemirovskij E.L., Načalo knigopečatnija v Valachii, Moskva 2008.

Nemirovskij E.L., Slavjanskie izdanija kirillovskogo (cerkovnoslavjanskogo) šrifta: 1491-2000. Inventar' sochranivšichsja èkzempljarov i ukazatel' literatury, vol. I, (1491-1550), Moskva 2009.

PANAitescu P.P., Începuturile și biruinţa scrisului în limba română, București 1965.

Panaitescu P.P., Liturghierul lui Macarie (1508) și începuturile tipografiei în ţările române, [in:] Contribuţii la istoria culturii românești, București 1971, p. 274-339. 
Panaitescu P.P., Les origines de l'imprimerie en langue roumaine, "Revue des études sud-est européennes" 6, 1, 1968, p. 23-37.

Papacostea Ş., Moldova în epoca Reformei. Contribuţie la istoria societăţii moldovenești în veacul al XVI-lea, "Studii Revistă de Istorie" 11, 4, 1958, p. 55-76.

Pascu G., Sufixele românești, București 1916.

Pavel E., Textul evanghelic în cultura românească, "Limba Română" 66, 1, 2012, p. 26-35.

Petrovici E., Note slavo-române III, “Dacoromania” 11, 1948, p. 184-193.

Philippi P., Ein Moldauer 1532 als Bibelübersetzer?, [in:] Land des Segens? Fragen an die Geschichte Siebenbürgens und seiner Sachsen, Köln-Weimar-Wien 2008, p. 105-109 (= "Zeitschrift für Siebenbürgische Landeskunde" 13, 1, 1990, p. 19-22).

Rosetti A., Cu privire la datarea primelor traduceri românești de cărţi religioase, "Limba Română" 7, 2, 1958, p. 20-22 (= Du nouveau sur la date des premières traductions roumaines de livres religieux, "Romania. Revue consacrée à létude des langues et des littératures romanes" 80, 317, 1959, p. 79-82).

SÂRKu P., [rec.] Psaltirea publicată la 1577 de Diaconul Coresi, Reprodusă cu un studiu și glosar comparativ la B. Petriceicu-Haşdeu - “Журнал Министерства Народного Просвещения” I “Žurnal Ministerstva Narodnogo Prosveščenija” 228, 1883, p. 319-397.

Simonescu D., Un Octoih al lui Bojidar Vucovici la noi și legăturile acestuia cu tipografia românească, "Revista istorică română" 3, 2-3, 1933, p. 227-233.

Sкок P., La terminologie chrétienne en slave: l'église, les prêtres et les fidèles, "Revue des études slaves" 7, 3, 1927, p. 177-198.

Sokolyszyn A., Sweipolt Fiol: The First Slavic Printer of Cyrillic Characters, "American Slavic and East European Review" 18, 1, 1959, p. 88-94.

SzéKely M., Biliarsky I., Tetraevanghelul Ieromonahului Macarie din Putna (1529), "Analele Putnei / The Annals of Putna" 2, 2013, p. 51-74.

TASMOWSKI L., În ajunul unei ediţii transliterate și electronice a Evangheliarului bilingv slavo-român de la Sibiu, [in:] Per Teresa. Studi e ricerche in ricordo di Teresa Ferro, vol. II, Obiettivo Romania, ed. G. Borghello et al., Udine 2009, p. 327-338.

Turdeanu E., L'activité littéraire en Moldavie à l'époque de Etiènne le Grand (1457-1504), [in:] Etudes de littérature roumaine et d'écrits slaves et grecs des Principautés roumaines, Leiden 1985, p. 113-161 (= "Revue des Etudes Roumaines" 5/6, 1960, p. 21-66].

VALMARIN L., La latinità dei rumeni come arma politica dalla Scuola transilvana a oggi, [in:] La latinité hier, aujourd'hui, demain, Actes du Congrčs international procurés par Georges et Ilinca Barthouil-Ionesco, Avignon - 10-13 mai 1978, ed. G. BARThouil, I. BARTHOUIL-Ionesco, Bucarest 1981, p. 401-424.

Veress E., Bibliografia română-Ungară, vol. III, Românii în literatura ungară și Ungurii în literatura română (1839-1878), Bucureşti 1935.

VV. AA., Istoria Romîniei, vol. I, ed. A. OŢetea, M. Berza et al., Bucureşti 1962. 


\begin{abstract}
At least from the $14^{\text {th }}$ to the $17^{\text {th }} \mathrm{c}$. - beyond their Middle Ages until their Early Modern Ages - the Rumanians belonged to the so-called Slavia Orthodoxa. Besides the Orthodox faith, they had in common with the Orthodox Slavs the Cyrillic alphabet until the $19^{\text {th }} \mathrm{c}$. and the Church Slavonic, which was the language of the Church, of the Chancery and of the written culture, until the $17^{\text {th }}$ c., although with an increasing competition of the Rumanian volgare. The crisis and decline of the Rumanian Slavonism, the rise of the local vernacular, have been related with Heterodox influences penetrated in Banat and Transylvania. Actually, the first Rumanian translations of the Holy Scriptures, in the $16^{\text {th }} \mathrm{c}$., were promoted, if not confessionally inspired, by the Lutheran Reformation recently transplanted in Banat and Transylvania (some scholars incline to a [widely] Hussite origin of these early translations). Not only Banat and Transylvania, but also Moldavia and Wallachia (the Principalities) were crossed by the border between the Latin and the Byzantino-Slavonic world, the Slavia and the Romània. Influences from the whole Slavia - the Orthodox and the Latin Slavia, the Southern, the Eastern and the Western one - met in the Carpatho-Danubian Space describing what will be derogatively called Slavia Valachica (i.e. Rumanian): a kaleidoscope of Slavic influences in Romance milieu. The appearance of Slavo-Rumanian texts, either with alternate or parallel Church Slavonic and Rumanian, revealed that in the middle of the $16^{\text {th }} \mathrm{c}$. the decline of Slavonism had already started. Mostly but not only in the western regions, beyond the Carpathians, which were under Latin rule, the Orthodox ("Schismatic") clergy was less and less confident with the Slavonic. This last still remained the sacred language though largely unintelligible, whilst the vernacular still lacked sacred dignity, besides being suspect to spread Heterodoxy. The Slavo-Rumanian Tetraevangelion of Sibiu (1551-1553) is the oldest version of a biblical text in Slavonic and Rumanian and contains the oldest surviving printed text in Rumanian. Apart from evoking icastically - by its twocolumns a fronte layout - the Slavic-Rumanian linguistic border, this fragment of a Four-Gospels Book (Mt 3, $17-27,55)$ can be considered in many senses a border text: geographically (the border between East and West), chronologically (the decline of Slavonism and the rise of the Rumanian Vernacular), culturally and confessionally (the border between the Latin [i.e. Catholic then Protestant too] West and the Byzantino-Slavonic East). This paper aims to reconstruct, as far as possible, the complex milieu in which the Tetraevangelion was translated, (maybe) redacted and printed, focusing on the Slavonisms in its Rumanian text. A special attention will be paid to any possible interaction between that mainly Latin (Lutheran-Saxon) milieu and the Rumanian Slavonism.
\end{abstract}

Keywords: Slavo-Rumanian, Sibiu, Lutheranism, Tetraevangelion, Gospel of Matthew, Filip Maler

Giuseppe Stabile

University of Naples "L’Orientale"

Department of Literary, Linguistic and Comparative Studies

via Duomo, 219

80138 Naples, Italy

gstabile@unior.it 